\title{
COVID-19 Mechanisms in the Human Body-What We Know So Far
}

\author{
Ashutosh Kumar ${ }^{1,2 *}$, Ravi K. Narayan ${ }^{1,3}$, Pranav Prasoon ${ }^{1,4}$, Chiman Kumari ${ }^{1,5}$, \\ Gurjot Kaur $^{1,6}$, Santosh Kumar ${ }^{1,7}$, Maheswari Kulandhasamy ${ }^{1,8}$, Kishore Sesham ${ }^{1,9}$, \\ Vikas Pareek ${ }^{1,10}$, Muneeb A. Faiq ${ }^{1,11}$, Sada N. Pandey ${ }^{1,12}$, Himanshu N. Singh ${ }^{1,13}$, \\ Kamla Kant ${ }^{1,14}$, Prakash S. Shekhawat ${ }^{1,15}$, Khursheed Raza ${ }^{1,16}$ and Sujeet Kumar ${ }^{1,17}$
}

OPEN ACCESS

Edited by:

Betsy J. Barnes,

Feinstein Institute for Medical

Research, United States

Reviewed by:

Fiachra Humphries,

University of Massachusetts Medical

School, United States

Philipp Niklas Ostermann,

Heinrich Heine University of

Düsseldorf, Germany

*Correspondence:

Ashutosh Kumar

drashutoshkumar@aiimspatna.org orcid.org/0000-0003-1589-9568

Specialty section: This article was submitted to Viral Immunology,

a section of the journal

Frontiers in Immunology

Received: 12 April 2021 Accepted: 11 October 2021 Published: 01 November 2021

Citation:

Kumar A, Narayan RK, Prasoon P,

Kumari C, Kaur G, Kumar S,

Kulandhasamy M, Sesham K,

Pareek V, Faiq MA, Pandey SN, Singh HN, Kant K, Shekhawat PS, Raza K and Kumar S (2021) COVID-19 Mechanisms in the Human BodyWhat We Know So Far.

Front. Immunol. 12:693938. doi: 10.3389/fimmu.2021.693938
${ }^{1}$ Etiologically Elusive Disorders Research Network (EEDRN), New Delhi, India, ${ }^{2}$ Department of Anatomy, All India Institute of Medical Sciences (AIIMS), Patna, India, ${ }^{3}$ Department of Anatomy, Andaman and Nicobar Islands Institute of Medical Sciences, Port Blair, India, 4 Pittsburgh Center for Pain Research, School of Medicine, University of Pittsburgh, Pittsburgh, PA, United States, ${ }^{5}$ Department of Anatomy, Postgraduate Institute of Medical Education and Research (PGIMER), Chandigarh, India, ${ }^{6}$ School of Pharmaceutical Sciences, Shoolini University, Solan, India, ${ }^{7}$ Department of Anesthesiology and Critical Care Medicine, School of Medicine, Johns Hopkins University, Baltimore, MD, United States, ${ }^{8}$ Department of Biochemistry, Maulana Azad Medical College (MAMC), New Dellhi, India, ${ }^{9}$ Department of Anatomy, All India Institute of Medical Sciences (AIIMS), Mangalagiri, Vijayawada, India, ${ }^{10}$ Center for Cognitive and Brain Sciences, Indian Institute of Technology Gandhinagar, Gandhinagar, Gujarat, India, ${ }^{11}$ New York University (NYU) Langone Health Center, NYU Robert I. Grossman School of Medicine, New York, NY, United States, ${ }^{12}$ Department of Zoology, Banaras Hindu University (BHU), Varanasi, India, ${ }^{13}$ Department of Systems Biology, Columbia University Irving Medical Center, New York, NY, United States, ${ }^{14}$ Department of Microbiology, All India Institute of Medical Sciences (AIIMS), Bathinda, India, ${ }^{15}$ Department of Clinical Hematology, National Institute of Medical Sciences, Jaipur, India, ${ }^{16}$ Department of Anatomy, All India Institute of Medical Sciences (AlIMS), Deoghar, India, ${ }^{17}$ Center for Proteomics and Drug Discovery, Amity Institute of Biotechnology, Amity University, Maharashtra, India

More than one and a half years have elapsed since the commencement of the coronavirus disease 2019 (COVID-19) pandemic, and the world is struggling to contain it. Being caused by a previously unknown virus, in the initial period, there had been an extreme paucity of knowledge about the disease mechanisms, which hampered preventive and therapeutic measures against COVID-19. In an endeavor to understand the pathogenic mechanisms, extensive experimental studies have been conducted across the globe involving cell culture-based experiments, human tissue organoids, and animal models, targeted to various aspects of the disease, viz., viral properties, tissue tropism and organspecific pathogenesis, involvement of physiological systems, and the human immune response against the infection. The vastly accumulated scientific knowledge on all aspects of COVID-19 has currently changed the scenario from great despair to hope. Even though spectacular progress has been made in all of these aspects, multiple knowledge gaps are remaining that need to be addressed in future studies. Moreover, multiple severe acute respiratory syndrome coronavirus 2 (SARS-CoV-2) variants have emerged across the globe since the onset of the first COVID-19 wave, with seemingly greater transmissibility/ virulence and immune escape capabilities than the wild-type strain. In this review, we narrate the progress made since the commencement of the pandemic regarding the 
knowledge on COVID-19 mechanisms in the human body, including virus-host interactions, pulmonary and other systemic manifestations, immunological dysregulations, complications, host-specific vulnerability, and long-term health consequences in the survivors. Additionally, we provide a brief review of the current evidence explaining molecular mechanisms imparting greater transmissibility and virulence and immune escape capabilities to the emerging SARS-CoV-2 variants.

Keywords: COVID-19, SARS-CoV-2, pathogenesis, immune response, organotropism

\section{INTRODUCTION}

The ongoing pandemic of coronavirus disease 2019 (COVID-19) has taken a heavy toll on human lives globally ( $\sim 4.8$ million until October 8, 2021, per WHO data). COVID-19 is caused by severe acute respiratory syndrome coronavirus 2 (SARS-CoV-2) (1), an enveloped positive-sense single-stranded RNA virus belonging to the genus betacoronaviruses ( $\mathrm{BCoVs}$ ). $\mathrm{BCoVs}$ have other members like SARS-CoV-1 and the Middle East respiratory syndrome coronavirus (MERS-CoV) that have caused the respiratory syndrome epidemic of SARS-2002/2003 and MERS-2012, respectively (1). The extreme paucity of knowledge, especially in the initial period, about the interaction of the new coronavirus strain, SARS-CoV-2, with the host greatly hampered the preventive and therapeutic management of the pandemic. However, the tremendous research done across the globe has resulted in rigorous scientific evidence on all the aspects of COVID-19 at an unprecedented speed and scale. The emerging facts about pathogenic mechanisms in COVID-19 have helped to put a break on the uncontrolled spread of the pandemic by the development of various preventive measures including effective vaccines and by improved therapeutic management. Even though currently there is no effective drug for COVID-19, the current status of the research is raising hope for the future. The emergence of multiple SARS-CoV-2 variants with greater transmissibility/virulence and immune escape capabilities is an unfortunate turn in the current course (2020-2021) of the pandemic. Evidence is emerging that can explain improved virus-host interactions and immune escape capabilities of the variants (2-4); however, whether the variants have altered tissue type/organ-specific pathogenesis is least understood. In this review, we precisely discuss the current evidence for the pathogenic mechanisms of COVID-19 in humans, including virus-host interactions, pulmonary and other systemic manifestations, immunological dysregulations, complications, host-specific vulnerability, and long-term health issues in survivors. The article is intended to impart a comprehensive understanding of the key pathogenic mechanisms driving clinical manifestations and patient outcomes in COVID-19 and highlight the knowledge gaps that may need further attention from the researchers. Additionally, we also discuss in brief the current evidence explaining molecular mechanisms imparting greater transmissibility and virulence and immune escape capabilities to the emerging SARS-CoV-2 variants.

\section{SYMPTOMATOLOGY OF COVID-19}

COVID-19 is primarily described as a disease-causing severe acute respiratory syndrome (SARS); however, the systemic manifestations involving other organs, including the central nervous system (CNS), are very usual (5) (Table 1). The onset of the symptoms occurs on average 5-6 days after exposure, and normally, those with mild symptoms recover within 2 weeks; however, in severe cases, the recovery may extend up to 6 weeks (Figure 1). Of note, in some patients, regardless of the disease severity, the symptoms may persist or recur for weeks or months following initial recovery (17). Persistence of the disease or after complete recovery and the emergence of new ailments, altogether known as "long COVID," is being reported in many survivors (17-19) (Figure 1). The clinical data presentations in COVID-19 patients have revealed some interesting facts; of the total cases, about $80 \%$ either are asymptomatic or have mild symptoms, while $\sim 14 \%$ develop severe symptoms, such as pneumonia, $5 \%$ develop critical symptoms, such as septic shock, respiratory failure, or multiorgan failure, and $\sim 2 \%$ of the patients die of the disease (20). Fatality is comparatively much higher in the aged and persons with comorbidities $(21,22)$.

Based on the review of current literature, "long COVID" is characterized by symptoms of fatigue, headache, dyspnea, and anosmia. It is more likely to occur in aged, people with high body mass index, and the female sex, and the symptoms may persist for 4-12 weeks. Also, the COVID patients who experienced more than five symptoms during the first week of illness may have significantly higher chances of developing "long COVID" [odds ratio $=3.53(2.76-4.50)](17)$. A recent study has indicated that certain "long COVID" symptoms may persist beyond a year, more particularly, fatigue, dyspnea, and neurological symptoms, such as anxiety and depression (23).

\section{VIRUS-HOST INTERACTIONS}

\section{SARS-CoV-2 Entry Into Host Cells}

Entry of SARS-CoV-2 into human cells is mediated by a cell surface receptor angiotensin-converting enzyme-2 (ACE2) (24) (Figure 2). ACE2 binds to the receptor-binding domain (RBD) of SARS-CoV-2 spike (S) protein. Furthermore, to enter into the host cell, the priming of the viral spike protein (S) is considered essential for its fusion to host cell membrane, which involves cleavage of the "S" protein by serine proteases called 
TABLE 1 | Systemic diversity of clinical manifestations in coronavirus disease 2019 (COVID-19).

\begin{tabular}{|c|c|c|}
\hline System & Symptoms & Study \\
\hline General & $\begin{array}{l}\text { Fever } \\
\text { Headache } \\
\text { Fatigue }\end{array}$ & $(6,7)$ \\
\hline Respiratory & $\begin{array}{l}\text { Dry cough } \\
\text { Difficulty to breathe } \\
\text { Congestion of nose } \\
\text { Runny nose } \\
\text { Sore throat }\end{array}$ & $(6,7)$ \\
\hline CNS and sensory organs & $\begin{array}{l}\text { Acute psychosis } \\
\text { Loss of sense of smell } \\
\text { Loss of sense of taste } \\
\text { Loss of speech } \\
\text { Dizziness } \\
\text { Impaired consciousness } \\
\text { Stroke } \\
\text { Ataxia } \\
\text { Seizure } \\
\text { Impaired vision } \\
\text { Pink eye } \\
\text { Hearing loss, otalgia, vertigo, tinnitus }\end{array}$ & $(8-11)$ \\
\hline Cardiac & $\begin{array}{l}\text { Acute chest pain/pressure } \\
\text { Arrhythmia } \\
\text { Heart failure }\end{array}$ & (12) \\
\hline Digestive & $\begin{array}{l}\text { Nausea and vomiting } \\
\text { Anorexia } \\
\text { Diarrhea } \\
\text { Abdominal pain }\end{array}$ & $(6,7,13)$ \\
\hline Renal & Cloudy urine with frequent urge & $(14)$ \\
\hline Musculoskeletal & Myalgia & (6) \\
\hline Skin, hair, and nail & $\begin{array}{l}\text { Rash or discoloration of fingers or toes } \\
\text { Hair fall and baldness } \\
\text { Red half-moon nail sign }\end{array}$ & $(6,15,16)$ \\
\hline
\end{tabular}

transmembrane serine protease 2 (TMPRSS2) or by cathepsin B or L (CTS-B or -L) and furin present in the host cell membrane (1) (Figure 2) [Reviewed in (1)].

ACE2 has been a known host cell entry receptor for some other CoVs as well, such as SARS-CoV-1 and HCoV-NL-63. TMPRSS2 and CTS-L are also known for SARS-CoV-1 and other SARS-related viruses (1). However, the inclusion of furin seems to be an evolutionary gain in SARS-CoV-2 in comparison to other SARS viruses [Reviewed in (1)]. Furin cleavage needs insertion of a peptide segment, furin cleavage site (FCS), containing multi-basic amino acids (PRRAR) at the S1/S2 intersection of viral spike protein $(\mathrm{S})$, which are not present in SARS-CoV-1 or other SARS-related viruses (25). Notably, FCS is known to be present in many other CoVs including MERS-CoV, HKU1-CoV, and OC43-CoV (26). The inclusion of FCS in the SARS-CoV-2 genome is speculated to be contributing to its high infectivity and transmissibility in comparison to other SARS viruses (25). FCS has also been observed in influenza viruses and is considered contributing to virulence (27). Currently, there is limited evidence whether FCS inclusion is contributing to the virulence of SARS-CoV-2 [Reviewed in (1)]. In a recent study, SARS-CoV-2 mutant lacking FCS in the spike protein was found to have reduced replication in Calu3 cells (a human respiratory cell line) and attenuated disease progression in a hamster pathogenesis model of COVID-19 (28).
Other than ACE2, concrete evidence for an alternative host cell entry receptor for SARS-CoV-2-neuropilin-1 (NRP1)-has been identified by recent studies $(25,26)$. NRP1 is abundantly expressed in multiple tissue types across the body, with very high expression in endothelial and epithelial cells, particularly, in the respiratory and olfactory epithelium. Cantuti-Castelvetri et al. (29) showed that NRP1 potentiates SARS-CoV-2 infectivity. Furthermore, Daly et al. (30) showed that the furin-cleaved S1 fragment of the spike protein can bind directly to cell surface NRP1, and blocking this interaction, using a small-molecule inhibitor or monoclonal antibodies, effectively reduces SARSCoV-2 infection.

\section{Tissue Tropism and Organotropism}

SARS-CoV-2 host cell entry factors are widely expressed across the tissue types in humans (31-33). Additionally, ACE2 is coexpressed with TMPRSS2/CTS-L in many tissue types, which is an essentiality for SARS-CoV-2 infection $(32,33)$. The extensive tissue tropism of SARS-CoV-2 is reflected in the diversity of the symptoms in COVID-19 patients (5). Multiorgan tropism of the SARS-CoV-2 has also been confirmed in the studies involving histopathological observations in the postmortem tissue samples from the infected patients (34) and laboratory infection of human tissue organoids (35). Figure 3 describes the tissue types that can get infected with SARS-CoV-2 based on the expression of host cell entry receptors and entry-associated host proteases.

\section{Hijacking of the Host Cell Machinery}

Recent studies have unraveled SARS-CoV-2-driven molecular mechanisms hijacking host cell machinery, particularly, for the production of proteins and energy production mechanisms (36, 37). The in vitro studies have provided robust evidence for extensive phosphorylation of SARS-CoV-2 viral proteins by the host proteome involved in activation of the host cell kinases and growth factor receptor (GFR) signaling, thus facilitating hijacking of the host protein machinery. The very first such evidence presented by Bouhaddou et al. (38) showed that SARS-CoV-2 infection of the host cells promotes casein kinase II (CK2) and p38 mitogen-activated protein kinase (MAPK) activation and production of diverse cytokines, leading to the shutdown of cyclin-dependent kinase (CDK) 1/2/5 and cell cycle arrest (38). Authors also noted a unique feature of SARS-CoV-2 that was least known for the respiratory viruses: viral infection markedly induced unique CK2-containing filopodia protrusions, which contained budding viral particles. The filopodia protrusions appeared to facilitate the transfer of the infective virus across the host cells. This pattern of molecular pathway activation by SARS-CoV-2 could potentially explain the hallmarks of host tissue injury in severe COVID-19, such as acute inflammation and epithelial cell damage and vascular endothelial dysfunction. The other prominent evidence was secondly provided by Klann et al. (37), showing that SARS-CoV-2 infection of a human colonic epithelium cell line-Caco-2 cells-activated GFR signaling and its downstream pathways. Additionally, the authors showed that inhibition of GFR signaling prevented replication of SARS-CoV-2 in host cells (37). Furthermore, 


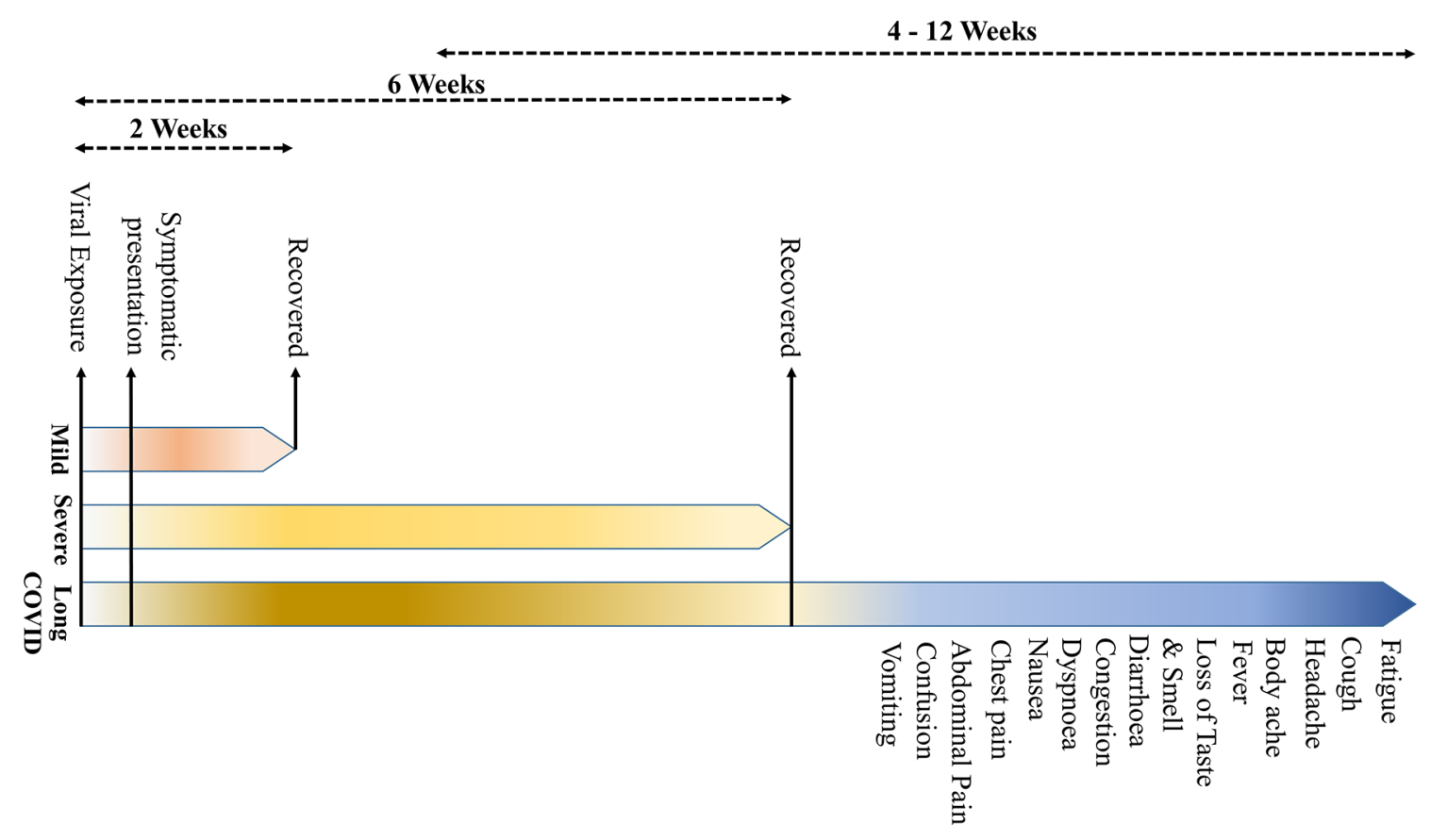

FIGURE 1 | The symptomatology of coronavirus disease 2019 (COVID-19). (The onset of the clinical symptoms occurs in average 5-6 days after exposure, and normally, those with mild symptoms recover within 2 weeks; however, in severe cases, the recovery may extend up to 6 weeks. Persistence of the disease or, after complete recovery, emergence of new ailments, together known as "long COVID" may occur in some patients. The "long COVID" is chiefly characterized by the presence of fatigue, headache, dyspnea, and anosmia, which may persist for 4-12 weeks.

another recent study involving a mouse model of COVID-19 has suggested that SARS-CoV-2-induced systemic toxicity causes downregulation of expression of genes affecting the energy production mechanisms in the cells, such as oxidative phosphorylation and the tricarboxylic acid (TCA) cycle, and epigenetic (DNA methylation) changes in the vital organs (38).

SARS-CoV-2 non-structural proteins (NSPs), more particularly, NSP1, which binds to the $40 \mathrm{~S}$ ribosomal subunit of the host cells, have been reported to cause the shutdown of mRNA translation in host cells (36). It has also been found to block retinoic acid-inducible gene I (RIG-I) and interferonstimulated genes (ISGs), which are key mediators of host innate immune response in case of viral infections (39). Another SARS-CoV-2 protein, NSP16, in conjunction with NSP10, protects the virus from host innate immune response by methylating the $5^{\prime}$-end of the virus-encoded mRNAs (thus mimicking host cellular mRNAs) (40).

Apart from the above-stated mechanisms, a mimicry of the SARS-CoV-2 spike protein to a human epithelial cell ionchannel, thus hampering its physiological functions, has also been shown recently. Anand et al. (41) have shown that S1/S2 cleavage site of spike protein (S) of SARS-CoV-2 has a striking protein sequence similarity to the furin-cleavable peptide segment (FCS) on the human epithelial sodium channel $\alpha$ subunit $(\mathrm{ENaC}-\alpha)$. The mimicry of the viral spike protein to $\mathrm{ENaC}-\alpha$ in host cells indicates that the virus can compete for the furin available in the infected host cells and thus may block proteolytic activation of $\mathrm{ENaC}-\alpha$. $\mathrm{ENaC}-\alpha$ has established roles in the development of acute respiratory distress syndrome (ARDS) mediated through immune cell activation and cytokines/chemokines $(42,43)$, indicating that this mechanism may have a role in the pathogenesis of ARDS in severe COVID19 patients.

\section{DYSREGULATION OF RENIN- ANGIOTENSIN-ALDOSTERONE SYSTEM (RAAS)-A KEY AXIS MAINTAINING PHYSIOLOGICAL HOMEOSTASIS}

Dysregulation of the renin-angiotensin-aldosterone system (RAAS) has been a characteristic feature in COVID-19 (44). RAAS regulates physiological hemodynamic balance involving all major organs, primarily liver, lung, heart, and kidney (22), and is also involved in the maintenance of electrolyte balance and vascular resistance; hence, it is a crucial determinant of systemic blood pressure and consequently cardiovascular health. SARSCoV-2-induced dysregulation of RAAS is mediated through its host cell entry receptor ACE2, which is an analog of ACE that performs a key step in the regulation of RAAS - the conversion of angiotensin I to angiotensin II. An ACE/ACE2 balance is considered to be a crucial factor in maintaining an optimum functionality of the RAAS. The SARS-CoV-2 infection supposedly downregulates $\mathrm{ACE} 2$, but not $\mathrm{ACE}$, and thus may be creating an imbalance of physiological ACE/ACE2 ratio $(9,17)$. Apart from 


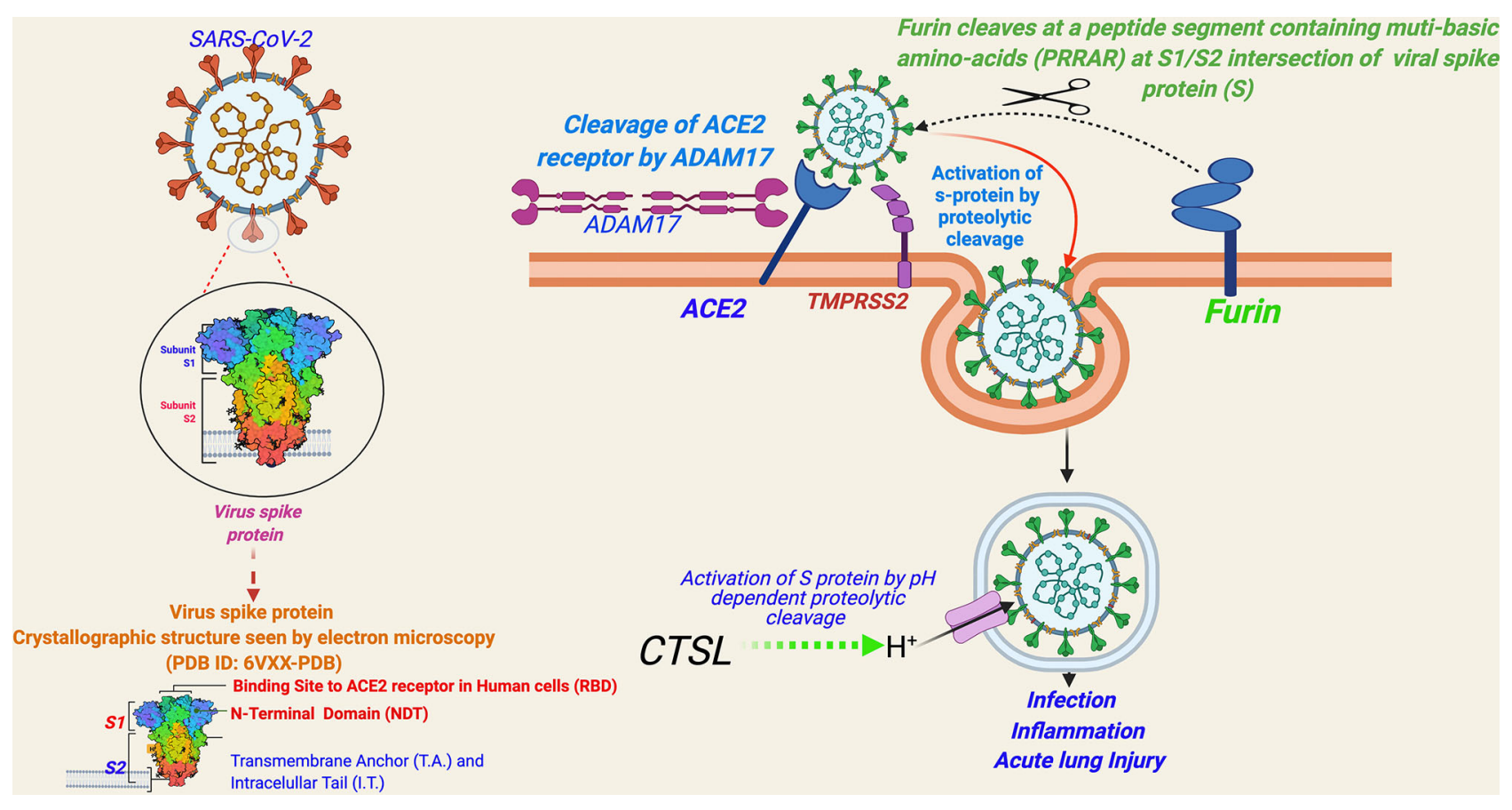

FIGURE 2 | A schema for severe acute respiratory syndrome coronavirus 2 (SARS-CoV-2) entry into human cells. [Entry of SARS-CoV-2 into human cells is mediated by a cell surface receptor angiotensin-converting enzyme-2 (ACE2). ACE2 binds to receptor-binding domain (RBD) of SARS-CoV-2 spike (S) protein. Furthermore, to enter into the host cell, the priming of the viral spike protein (S) for its fusion to host cell membrane is done by host cell proteases, which involves cleavage of ' $S$ ' protein by the serine proteases, transmembrane serine protease 2 (TMPRSS2) or Cathepsin B or L (CTS-B or -L), and furin present in the host cell membrane. CTS-B or -L) acts primarily inside the endosomes. Furin cleavage site (PRRAR), present at the intersection of S1 and S2, is considered an evolutionary gain in SARS-CoV-2.

that, a SARS-CoV-2 binding causes downregulation of ACE2 in RAAS components, which can induce activation and release of pro-inflammatory markers causing tissue injury (42). An ACE2mediated dysregulation of RAAS is a key step in COVID-19 pathogenesis and contributes significantly to the comorbidityassociated mortality, vascular thrombosis, organ-specific morbidity, and multiorgan failures, which we discuss in detail afterward in this article in the related subsections. A schematic representation of virus binding-induced ACE2-mediated dysregulations of RAAS in COVID-19 is summarized in Figure 4.

\section{MULTISYSTEM INVOLVEMENT IN COVID- 19: UNDERSTANDING UNDERLYING MECHANISMS}

The extensive distribution of the SARS-CoV-2 host cell entry factors in the human body indicates that the virus can potentially infect most of the organs and tissue types. Initially, it was perceived that the primary organ involved in COVID-19 pathogenesis is the lung; however, the accumulating body of evidence over time has established that COVID-19 is a systemic disease with extremely diverse manifestations (5) (Table 1). In many cases, the patients particularly present with the nonrespiratory symptoms, involving single or multiple other organs, including the brain (5). A comprehensive review of the current literature suggests that the multisystem involvement in COVID-19 can be largely explained by the widespread distribution of SARS-CoV-2 host cell entry receptors, direct viral toxicity, dysregulated host immune response, involvement of RAAS and systemic hyper-inflammatory response against the infection, and macrovascular and microvascular thrombosis. The current empirical evidence on all these aspects, involved in the pathophysiology of COVID-19, about the key physiological systems is mentioned below.

\section{Respiratory System}

SARS-CoV-2 cell entry receptors are expressed by multiple cell types along the respiratory tract. In the upper respiratory tract, ciliated nasal secretory epithelial cells co-express ACE2 and TMPRSS2 in abundance (32). In the lower respiratory tract, ACE2 and TMPRSS2 are co-expressed, more abundantly, in type 2 pneumocytes than type 1; additionally, both receptors are expressed in the goblet, club, enteroendocrine, bronchial cells and endothelial cells of the pulmonary vasculature $(32,33,44)$. Though the mild respiratory symptoms can be attributed to infection in the upper respiratory tract, the characteristic SARS or ARDS is caused when lung cells, primarily type 2 pneumocytes and pulmonary vascular endothelial cells, are infected (45). Severe lung inflammation may ensue with infection of these cells first by the involvement of resident macrophages and then by the recruitment 


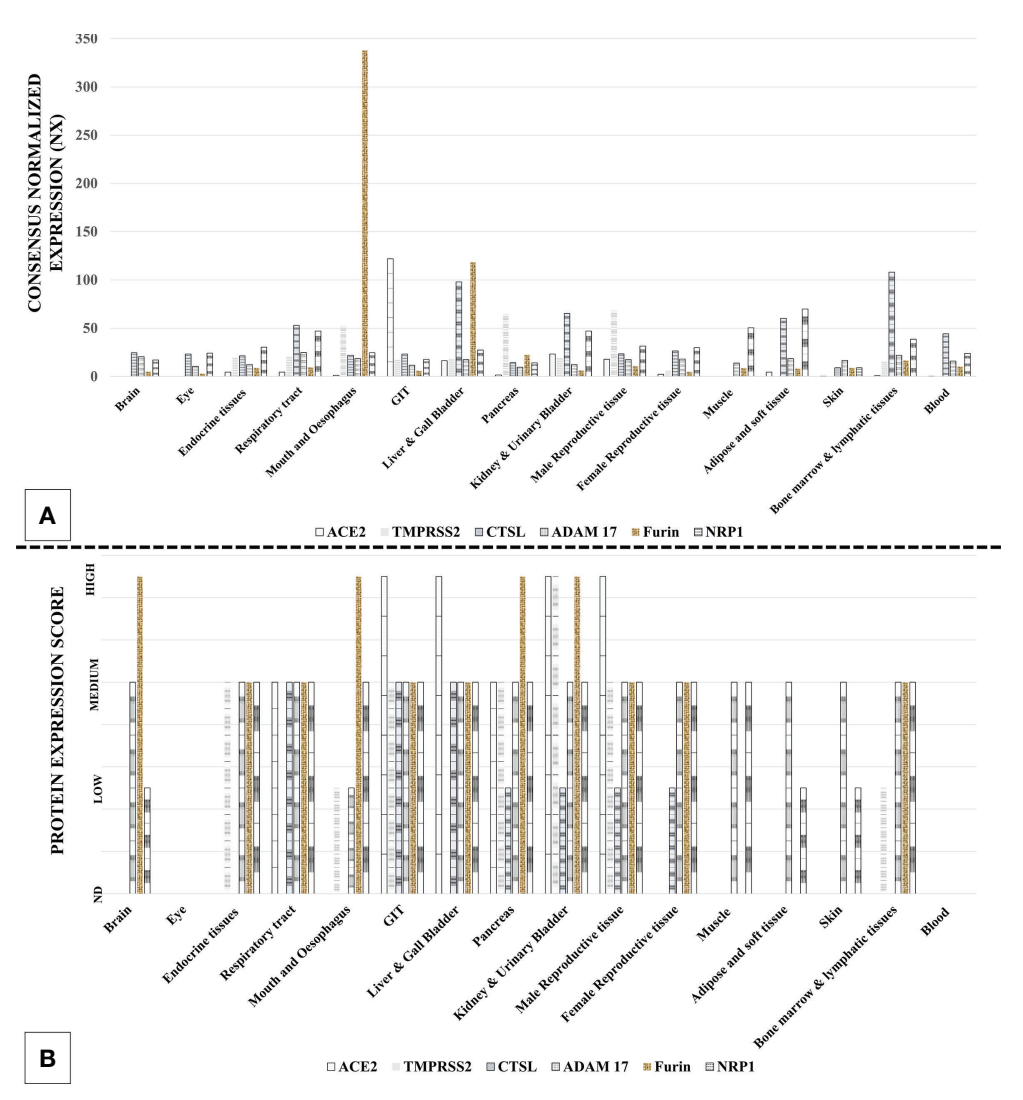

FIGURE 3 | Expression of severe acute respiratory syndrome coronavirus 2 (SARS-CoV-2) host cell entry receptor and entry-associated proteases in human tissue types. (A) mRNA. (B) Protein. [Data source: Human Protein Atlas (https://www.proteinatlas.org/)].

of peripheral macrophages and other immune cells, such as neutrophils and $\mathrm{T}$ cells $(20,45)$. The hampered production of surfactants (by type 2 pneumocytes) and consolidation of the accumulating exudates cause a collapse of the alveoli and induce pneumonic changes (46). Uncontrolled initial inflammation may cause the release of more pro-inflammatory cytokines and recruitment of peripheral immune cells, thus in a vicious cycle inducing more tissue injury (20). Pulmonary vascular endothelialitis and subsequent thrombosis, primarily of the microvessels, marked by elevated blood levels of fibrin degradation products (FDPs), Ddimer, and prothrombin time (PT) also contribute effectively to the lung pathology $(20,45,47)$.

\section{Cardiovascular and Renal Systems}

Cardiac myocytes, endothelium of coronary vessels, and fibrocytes are known to have significant expression of ACE2 and serine proteases, primarily TMPRSS2 (48). Cardiac symptoms may arise because of direct myocardial injury caused by the virus $(49,50)$. Additionally, SARS-CoV-2-driven RAAS dysregulation may cause increased incidences of thromboembolism, and the hypertensive episodes may be ensued by persistent constriction of systemic and coronary vessels $(51,52)$. Furthermore, an inflammation in the coronary arteries may speed up the formation of plaques, causing blockage and thus the ischemic changes leading to heart failure $(12,53)$. Electrolyte imbalance induced by the RAAS dysregulation may be another mechanism leading to heart ailments, especially hypokalemia can cause hyperpolarization of the cardiac myocytes leading to arrhythmia (53). The hypokalemia in COVID-19 may also be caused by direct viral-mediated directed myocardial injury leading to decreased cardiac output, thus activating aldosteronemediated renal excretion of potassium ions $(53,54)$.

Renal involvement is highly indicative in COVID-19, taking into account the significant expression of SARS-CoV-2 host cell entry receptor ACE2 and associated proteases, particularly TMPRSS2 in epithelial cells of renal tubules and podocytes of the glomeruli $(33,55)$. In that line, acute renal involvement and the evidence of virus-induced injury, including the presence of viral particles in the renal tubules upon postmortem histopathological examination, have been reported (34). However, the prevalence of direct renal/kidney involvement in COVID-19 is low if compared to the other key systems/organs (56). Renal injury may also be secondary to ARDS and cytokine storm-induced sepsis. It may also be caused by ACE2-mediated dysregulation of RAAS or due to multiple iatrogenic causes, such as a fallout of intensive care unit management or mechanical ventilation and nephrotoxic effects of the drugs (57). 


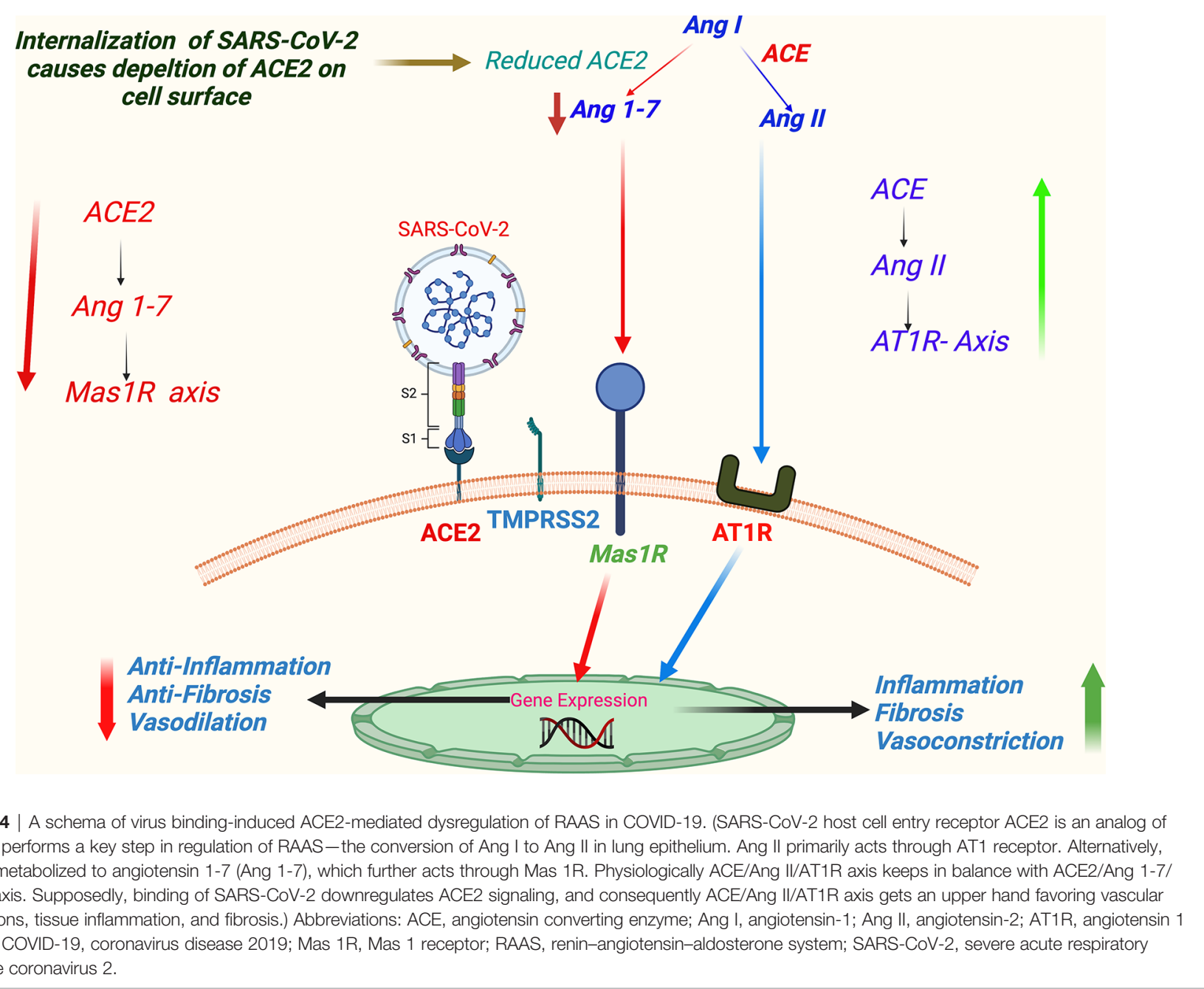

\section{Digestive System}

Prominent digestive symptoms have been noted in many COVID-19 patients $(6,13)$, and SARS-CoV-2 particles have been detected in the cells, with evidence of inflammatory lesions, in the gastrointestinal tissues, in multiple postmortem studies $(34,58)$. SARS-CoV-2 host cell entry factors (ACE2 and TMPRSS2) are enriched in intestinal tissue (13), and successful viral invasion has been shown in human intestinal organoids (59, $60)$ and animal model studies, including in primates $(61,62)$.

Whereas, at present, there is sufficient evidence confirming that SARS-CoV-2 can infect the gastrointestinal tract (GIT), how the virus reaches this is yet not well understood. A fecal-oral route of the viral entry is the most plausible explanation for this (62). Shedding of infectious SARS-CoV-2 in feces was detected in some COVID-19 patients, although it has not been a regular finding (62). It is intriguing how SARS-CoV-2 survives extremes of the $\mathrm{pH}$ within the digestive system milieu (gastric, 1.5-3.5; pancreatic, 7.5; bile acid, 7-8) while passing along the length of the GIT. SARS-CoV-2 is known to survive at a wide range of $\mathrm{pH}$ values at room temperature $(\mathrm{pH} 3-10)$ (13). RNA viruses like influenza A and B (when swallowed) can survive the extremes of
$\mathrm{pH}$ and maintain infectivity with the help of the mucus cover lining the GIT, allowing their safe passage and even excretion in feces (63). As mucus cells are abundant throughout the GIT, they can contribute to the carriage and survival of SARS-CoV-2 (13).

Of note, the healthy intestinal mucosa may not be well conducive for the entry of the virus owing to the presence of a unique multilayer barrier system, though the presence of a prior inflammatory condition that disrupts the mucosal barrier may make that permissive $(13,64)$. Additionally, inflammatory conditions in GIT may support entry of the virus by inducing the expression of ACE2 in the mucosal epithelium (13). Thus, a prior intestinal inflammatory condition, like inflammatory bowel disease (IBD), may increase the susceptibility to SARS-CoV-2 infection through fecal-oral transmission (13). The composition of the gut microbiome of the subject is another important factor influencing contractibility and severity of symptoms (65) (discussed further in subsection Gut Microbiome under section Host Factors Affecting Transmissibility, Severity, and Patient Outcomes).

Other than the fecal-oral route, an alternative route of viral entry to the GIT cells can be through the tissue microvasculature (13). 
As per current evidence, the blood is known to carry and transmit SARS-CoV-2, and vascular endothelium expresses ACE2 and TMPRSS2 abundantly $(45,66)$. Viral infection-induced inflammation and tissue injury including rupture of the intercellular junctional complexes may make the small vessels permeable for passage of the virus (67).

Other than GIT, tissue injury has also been noted in the other components of the digestive system, viz., liver and biliary duct, and pancreas $(34,68)$. Elevation of the liver enzymes has been a frequent finding in severe cases of COVID-19 (68). Paradoxically, there has been no clear evidence of a direct viral invasion to the liver tissue (34); however, model studies in human tissue organoids have shown that SARS-CoV-2 can infect hepatocytes, as well as cholangiocytes in the biliary ductal epithelium (35). Of note, proteomic and transcriptomic studies suggest that the expression of key viral host cell entry receptor ACE2 is primarily limited to cholangiocytes (69). Observing the limited expression of ACE2 in hepatic tissue, there remains a plausibility that any hepatic impairment in COVID-19 may be primarily not due to direct viral injury but indirect reasons, such as systemic hyper-inflammation, dysregulated immune response, and thrombosis of microvessels. Pancreatic involvement in COVID-19 is intriguing, as the severe glycemic impairment including the onset of new diabetes (also discussed later in subsection Comorbidities) has been noted in the patients $(70,71)$; however, a clear evidence, showing that COVID-19 can do this on its own accord, is still lacking [Reviewed in (72)]. Although there has been vague evidence in high-throughput proteomic and transcriptomic studies on the secretion of ACE2 by the pancreatic components (13), the studies involving single-cell RNA sequencing clearly showed significant expression of ACE2 in the beta cells secreting insulin, and SARS-CoV-2 was shown to be capable of infecting endocrine cells (alpha and beta) of the human pancreatic organoids (35).

\section{Nervous System}

Mild neurological symptoms in most of the cases, like headache, nausea, vomiting, dizziness, loss of the sense (smell and taste), and, in certain cases, severe symptoms like ataxia, convulsions, altered consciousness, ischemic or hemorrhagic stroke, acute disseminated encephalomyelitis (ADEM), meningitis, encephalitis, and rarely Guillain-Barré syndrome variants (Miller Fisher syndrome and polyneuritis cranialis) (8, 73-76), and new onset of psychotic symptoms (77) have been reported in COVID-19. Autopsy studies in COVID-19 deceased have shown widespread brain lesions (mostly reflecting acute hypoxicischemic injury) (78). Although rare, the viral RNA is also detected in brain tissue (78) and the cerebrospinal fluid (CSF) $(74,79)$ of the COVID-19 deceased.

How SARS-CoV-2 enters the central nervous system and mediates the pathogenesis of neurological symptoms in COVID19 patients is now getting explained in light of emerging facts (80). The most likely route of viral spread to the brain is transneuronal spread through the olfactory nerves. In association, the hematogenous route after breaching the bloodbrain barrier (BBB) is also possible (67). The studies noted significant expression of ACE2 and TMPRSS2 in cells of olfactory epithelium and myelin (oligodendrocytes) and neurovascular endothelium in humans (80). In addition, model studies in transgenic mice, which expressed human ACE2, have demonstrated the intracranial spread of SARS-CoV-2 to the parts of the brain via the olfactory pathway following intranasal inoculation (80). The mounting pieces of evidence strongly favor the neuroinvasive potential of SARS-CoV-2. Furthermore, the new onset of psychotic symptoms in some patients of COVID-19 (77) indicates a synaptic pathology occurring in the brain regions associated with executive functions.

Studies suggest that neurological symptoms (including the loss of smell and taste) may arise due to the direct neuropathic effect of the virus. Alternatively, it can also be an indirect effect of cytokine-induced neuroinflammation or immune cell-mediated $(81,82)$ effect on neurons (or glial cells) or endothelial cells of cerebral microvasculature inducing cellular apoptosis and increased vascular permeability and edema of the related brain tissue.

The mediation of SARS-CoV-2 infection in the brain through the recently proposed alternative receptor-NRP1-is a strong plausibility. Interestingly, NRP1 has significant expression in the human brain including olfactory neurons. The proof of the concept for NRP1-mediated SARS-CoV-2 entry into the brain is received from a recent study by Cantuti-Castelvetri et al. (29) demonstrating the presence of SARS-CoV-2 spike protein in NRP1-expressing neurons and endothelial cells of capillaries and medium-size vessels of olfactory bulb and tract in brain autopsy specimens from COVID-19 deceased. The authors also demonstrate in mice, following intranasal administration, NRP1-dependent delivery of virus-size nanoparticles $(80 \mathrm{~nm}$ diameter) to the olfactory epithelium and neuronal cells of the olfactory bulb and central nervous system (cortex) that signifies the olfactory pathway as a route for SARS-CoV-2 entry into the brain (29).

The neurological symptoms may also arise due to several other reasons, such as metabolic encephalopathy arising from dysfunction of the vital organs (like lung, liver, and kidney) (7) or increased risk of neurovascular thrombosis in patients with severe COVID-19 (83), associated comorbidities, or age-related neurovascular pathologies.

\section{Other Systems and Tissue Types}

COVID-19 is said to involve not only the key physiological systems (discussed above) but also almost all other systems (5), including sensory organs, viz., eyes (11) and ears (10), and integument, viz., skin, hair, and nails $(15,16)$. The pathological involvement of most of these systems/tissue types can also be predicted based on the expression of viral host cell entry factors (31) (Figure 2). Multiple mechanisms can be responsible for the injury of the SARS-CoV-2-infected tissue, viz., a direct injury caused by the viral cytotoxicity (1), endothelial dysfunction mediated through the viral host cell entry receptor ACE2 and consequent vascular thrombosis (45), or inflammatory damage owing to an excessive immune response against the infection (20), or it can be due to a virus-independent mechanism, such as 
certain tissue-specific immunopathologies that are currently not well explained (84).

\section{HOST IMMUNE RESPONSE TO SARS- COV-2 INFECTION}

SARS-CoV-2 infection ensues varying immune responses in the different individuals, which decide the severity of the symptoms (85). Some individuals get away with the mildest of the symptoms or remain completely asymptomatic; in contrast, in others, the viral infection leads to severe disease manifestations resulting in ARDS and multiorgan failure (20). Similar to other viral infections, a cytokine-mediated innate defense is the first immune response in the infected individuals. A peculiar form of systemic hyper-inflammatory state, characterized by very high levels of pro-inflammatory cytokines, known as "cytokine storm" (CS) is commonly observed in patients with severe COVID-19 (20). Of note, CS is not peculiar to COVID-19, and it has been a characteristic finding in the severe stages of many other respiratory viral diseases, such as SARS, MERS, and influenza (86). However, SARS-CoV-2-induced CS is different compared to other respiratory viruses, as SARS-CoV-2 does not necessarily induce a common cytokine signature, such as interleukin (IL)-2, IL-10, IL-4, or IL-5 (87). In COVID-19, CS is characterized by a particular set of cytokines highly increased in the serum of the patients, such as IL-2, IL-7, granulocyte-macrophage colonystimulating factor (GM-CSF), granulocyte colony-stimulating factor (G-CSF), Interferon gamma-induced protein 10 (IP10), macrophage inflammatory protein $1-\alpha$ (MIP1- $\alpha$ ), monocyte chemoattractant protein 1 (MCP-1), Tumour necrosis factor $\alpha$ (TNF $\alpha$ ) and Interferon $\gamma($ IFN- $\gamma$ ). The circulating concentrations of chemokine (C-X-C motif) ligand-10 (CXCL10), chemokine (C-C motif) ligand 2 (CCL2), IL-2R, IL-6, TNF $\alpha$, C-reactive protein (CRP), and ferritin are significantly higher in those needing admission to intensive care units (ICUs) (87). Furthermore, it is targeted particularly to the dysregulation of the type-I IFN response and its downstream cytokines (87).

Researchers worldwide are endeavoring to understand the exact reasons for the heightened innate immune response seen in COVID-19 patients. A review of the existing literature suggests that it may be partly explained by the known facts about unique host-pathogen interactions occurring in respiratory viruses [(Reviewed in (20)]. The first defense of the host against a viral infection is marked by the rise of the key innate immune response molecule-IFN $\alpha$ (20). Similar to SARS and MERS (88), a delayed IFN $\alpha$ response has been observed in COVID19, which indicates it being a virus-mediated mechanism facilitating the viral cell entry. A delayed immune response would facilitate entry of the virus in the lung epithelium and that in turn would lead to an intense inflammatory response caused by incremental recruiting of the wide repertoire of innate immune cells (89). Interestingly, different from the other respiratory viruses, such as SARS-CoV, MERS-CoV, and influenza virus type A (IVA), a very distinctive strategy seems to be used by SARS-CoV-2 (90). SARS-CoV-1, MERS-CoV, and
IVA cause complete dampening of the IFN or chemokine (the pro-inflammatory cytokines with chemoattractant properties)mediated innate immune response at the time of infection. In contrast, SARS-CoV-2 showed a dampened IFN (type I, and also type III) response but paradoxically highly elevated chemokines (89) (Figure 5). The dampening of early IFN response against SARS-CoV-2 infection is mediated by a viral protein ORF3b (90). This unique dichotomy in the host innate immune response in COVID-19 can promote viral invasion of the respiratory epithelium (and epithelial cells at other sites) and facilitate their viral replication. High viral load in the infected host epithelial cells in turn can induce tissue injury and, as a consequence, incremental secretion of chemokines and recruitment of circulating immune cells (Figure 5). A hyperactive innate immune response would paradoxically hamper viral clearance and promote further viral replication (1).

Optimum $\mathrm{T}$ cell-mediated and humoral-mediated adaptive immune responses are usual in asymptomatic and mild symptomatic cases. Conversely, a subthreshold and delayed protective $\mathrm{T}$ cell-mediated and humoral-mediated adaptive immune responses in symptomatic patients are pronounced in the patients with severe COVID-19 in the initial period. However, the survivors showed a robust and durable adaptive immune response (91) [Reviewed in (92)].

Interestingly, Th1 cells, a type of activated CD4 T cells, and lung tissue-resident memory-like Th17 (Trm 17) cells characterized by potentially pathogenic cytokine expressions of IL-17A and GM-CSF are observed to be higher in patients with severe disease in comparison to those with moderate disease (93). Interestingly, GM-CSF was found distinctively raised only in severe cases of COVID-19 and not in influenza when both conditions were compared (94).

Lymphocytopenia, particularly for $\mathrm{T}$ cells and more intensively for CD8 $\mathrm{T}$ cells, is a common observation regardless of the disease stage and severity in COVID-19 cases (22). However, lymphocytopenia correlated with the severity of the symptoms, and very low numbers of $\mathrm{T}$ cells predicts poor patient outcomes $(95,96)$. In contrast, in most of the patients with mild or moderate symptoms and with stable lymphocyte count, neutralizing antibodies [immunoglobulin G (IgG)] for a viral spike or other proteins appear nearly between 18 and 21 days and outcomes are fairly good. Molecular reasons for the killing of T cells in COVID-19 are little understood (97). Of note, $\mathrm{T}$ cells show less expression of SARS-CoV-2 entry receptors, providing a hint that the virus-mediated $\mathrm{T}$-cell demise in the infected individuals may be occurring by some other mechanism rather than through viral receptor signaling (85). SARS-CoV-2mediated atrophy and lesion of the human lymphoid tissues, such as spleen and lymph nodes, has also been evidenced in recent studies $(58,98,99)$. The analysis of laboratory parameters of COVID-19 patients suggests that high levels of proinflammatory markers, or the cytokine storm, may be a potential reason for the killing of the T cells (100). TNF- $\alpha$, IL-6, IL-8, and IL-10 levels are found to be significantly increased and negatively correlate to T-cell counts in severe COVID-19 (100). That high serum levels of TNF- $\alpha$ and other cytokines 


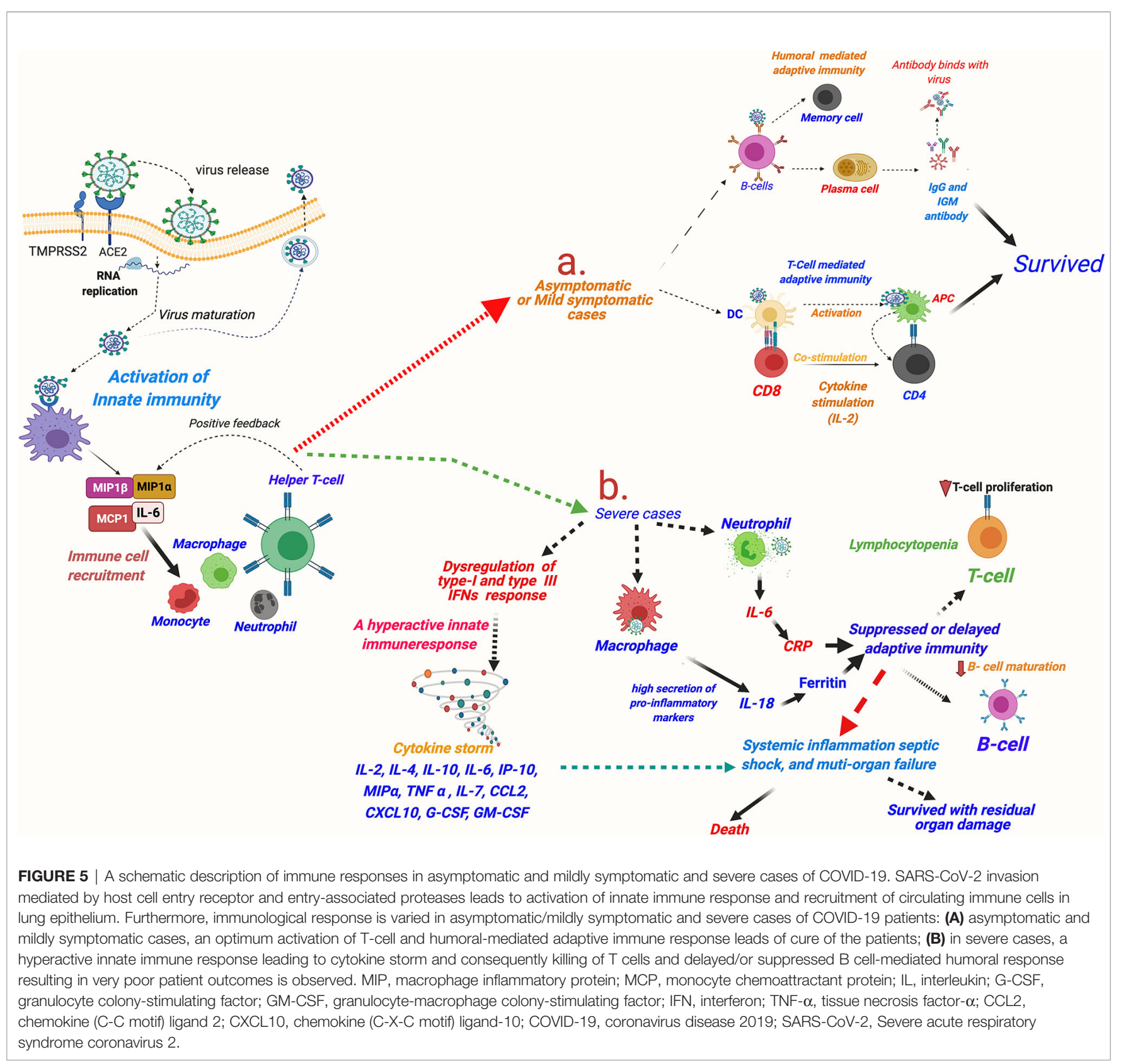

induce apoptosis of $\mathrm{T}$ cells is well known in inflammatory diseases, including SARS and MERS (101).

Based on the review of the current evidence (discussed above), the improved replication in host cells resulting in greater viral load and virus-mediated dysregulation of innate as well as adaptive host immune response seems to be the most important mechanism contributing to higher virulence and mortality risk to SARS-CoV-2 with respect to influenza and other BCoVs (SARS-CoV-1 and MERS-CoV). Hence, along with reducing viral replication with antiviral drugs, managing dysregulated host immune response, specifically innate, using immunomodulators, anti-inflammatory cytokines, and proinflammatory cytokine/or pathway-targeted antibodies becomes an important therapeutic strategy in COVID-19 [(Reviewed in (20)]. Noteworthy, apart from being a result of the SARS-CoV-2-induced dysregulation, the hyperactive innate immune response may be contributed by the factors intrinsic to the subject $(102,103)$. Specifically, in some young and healthy adults with no obvious comorbidity, the development of severe COVID-19 and subsequent mortality strongly indicates the presence of a subject-specific vulnerability (103). This is likely that such individuals may have a genetic or immunophenotypic predisposition for developing severe illness $(102,103)$. We discuss this issue in greater detail in the section Host Factors Affecting Transmissibility, Severity, and Patient Outcomes (subsection Genetic and Immunophenotypic Factors). 


\section{PATHOPHYSIOLOGY OF VASCULAR THROMBOSIS AND MULTIORGAN FAILURE}

Thrombosis of the macrovessels and microvessels across the organs, particularly in the pulmonary vasculature, has been a prominent manifestation in severe COVID-19. Vascular thrombosis has been linked to the genesis of multiorgan failures and associated with very poor disease outcomes, including enhanced mortality. Multiple reasons have been suggested for the etiology of vascular thrombosis in COVID19 , such as toxicity of viral proteins, high levels of proinflammatory markers and cytokine storm, the prothrombotic impact of severe illness, and the iatrogenic causes $(47,104,105)$. However, a SARS-CoV-2 binding-induced ACE2-mediated mechanism seems to be at the root of all these mechanisms $(45,105,106)$. SARS-CoV-2 host cell entry factors ACE2 and TMPRSS2 co-express in endothelial cells of human blood vessels and microvasculature (45) and blood cell components particularly platelets (106). SARS-CoV-2 binding-induced downregulation of ACE2 can induce activation and release of pro-inflammatory markers and thus can cause injury of vascular endothelium $(45,107,108)$. Additionally, a reversal of ACE/ ACE2 ratio in the vascular endothelium dysfunction can also induce thrombosis (45). A lower ACE/ACE2 ratio in the vascular endothelium is known to prevent prothrombotic cascade from activation by catalyzing the degradation of angiotensin I (Ang I) to inactive angiotensin 1-9 and angiotensin II (Ang II) to angiotensin 1-7 with antiproliferative, antifibrotic, and vasodilatory functions through $G$ protein-coupled Mas receptors $(45,105)$. Conversely, a higher ACE/ACE2 ratio allows increased conversion of Ang I to Ang II and binding of the latter to its type 1 (AT1) receptors, thus can induce vasoconstriction, inflammation, and fibrosis, and eventually vascular thrombosis $(45,105)$. Furthermore, SARS-CoV-2mediated downregulation of ACE2 in vascular endothelium can activate the kallikrein-bradykinin pathway, inducing platelet aggregation and leaking of the vessels that can further add to the thrombotic episodes (45). Alternatively, direct binding of SARS-CoV-2 to ACE2 expressed on the platelets may also induce platelet aggregation and consequent thrombosis (106).

Plausibly, the activation of the host "complement system" caused by viral protein toxicity and cytokine-induced systemic inflammatory response may significantly add to the pathogenesis of vascular thrombosis (20). Gao et al. (109) recently demonstrated in mice that the $\mathrm{N}$ proteins of the BCoVs (SARS-CoV, MERS-CoV, and SARS-CoV-2) bound to Mannan-binding lectin serine protease-2 (MASP-2) (a key serine protease involved in complement activation) that led to aberrant activation of the host complement system and consequently microvascular thrombosis and aggravated inflammatory lung injury. Interestingly, the viral activation of the complement system was reversed with the application of MASP-2 antibodies (109).

In the vessels of the lung, primarily of the microvessels, neutrophilia and the formation of extracellular neutrophils traps (NETs) are being frequently observed in severe cases. The NETosis activation leads to increased concentrations of intracellular reactive oxygen species (ROS) in neutrophils, which induces endothelial dysfunction and activates coagulation pathways (both extrinsic and intrinsic), thus it can add to the ongoing event of vascular thrombosis. Hypoxiainduced hyperviscosity and upregulation of the HIF- $1 \alpha$ (hypoxia-inducible factor 1 alpha) signaling pathway can be additional factors contributing to the thrombosis (5).

Vascular thrombosis added with the direct viral protein toxicity of the infected tissue and RAAS dysregulation-mediated hemodynamic imbalance, systemic hyper-inflammation, and toxic shock syndrome arising from the cytokine storm may culminate in multiorgan failure $(105,110,111)$. The presence of the comorbidities and host-specific vulnerability for the severe disease symptoms may further contribute to the pathogenesis of the multiorgan failures $(21,112)$.

A schematic description for ACE2-mediated dysfunction of vascular endothelium involving RAAS and consequent thrombotic incidences and development of multiorgan failures in COVID-19 patients is summarized in Figure 6.

\section{HOST FACTORS AFFECTING TRANSMISSIBILITY, SEVERITY, AND PATIENT OUTCOMES}

Specific population groups, primarily men, aged, and those suffering from comorbidities, have been affected more aggressively by COVID-19 (21). The reasons why the disease affects more these specific population groups are now being gradually unraveled. Emerging scientific evidence indicates the multiple factors intrinsic to the host that are responsible for such poor outcomes in selected individuals (21). In this section, we are discussing, in brief, the current empirical evidence on the pathological basis of involvement of the key host intrinsic factors, which have been found to significantly influence transmissibility, severity, and patient outcomes for COVID-19.

\section{Age}

Higher disease severity and mortality in individuals aged $>50$ years, more particularly in the elderly, are common observations in COVID-19 $(113,114)$. Several biological mechanisms have been suggested for this (115). The immunosenescence in elderly individuals could be the primary reason (116). The availability of naive $\mathrm{T}$ cells, the ratio of CD4/CD8 $\mathrm{T}$ cells, and $\mathrm{T}$ regulatory (Treg) cells decrease with aging (117). Plausibly, the immunosenescence compromises the response against a new pathogen, such as SARS-CoV-2 (118). Furthermore, the protective inflammatory response becomes worse with aging (116). In addition, elderly persons are most likely to have serious comorbidities (115).

In contrast, in the pediatric age group, a lesser number of cases and reduced fatality have been reported. Surprisingly, a rare multisystem inflammatory syndrome in children (MIS-C) has been reported across the world in this age group (119). MIS-C 


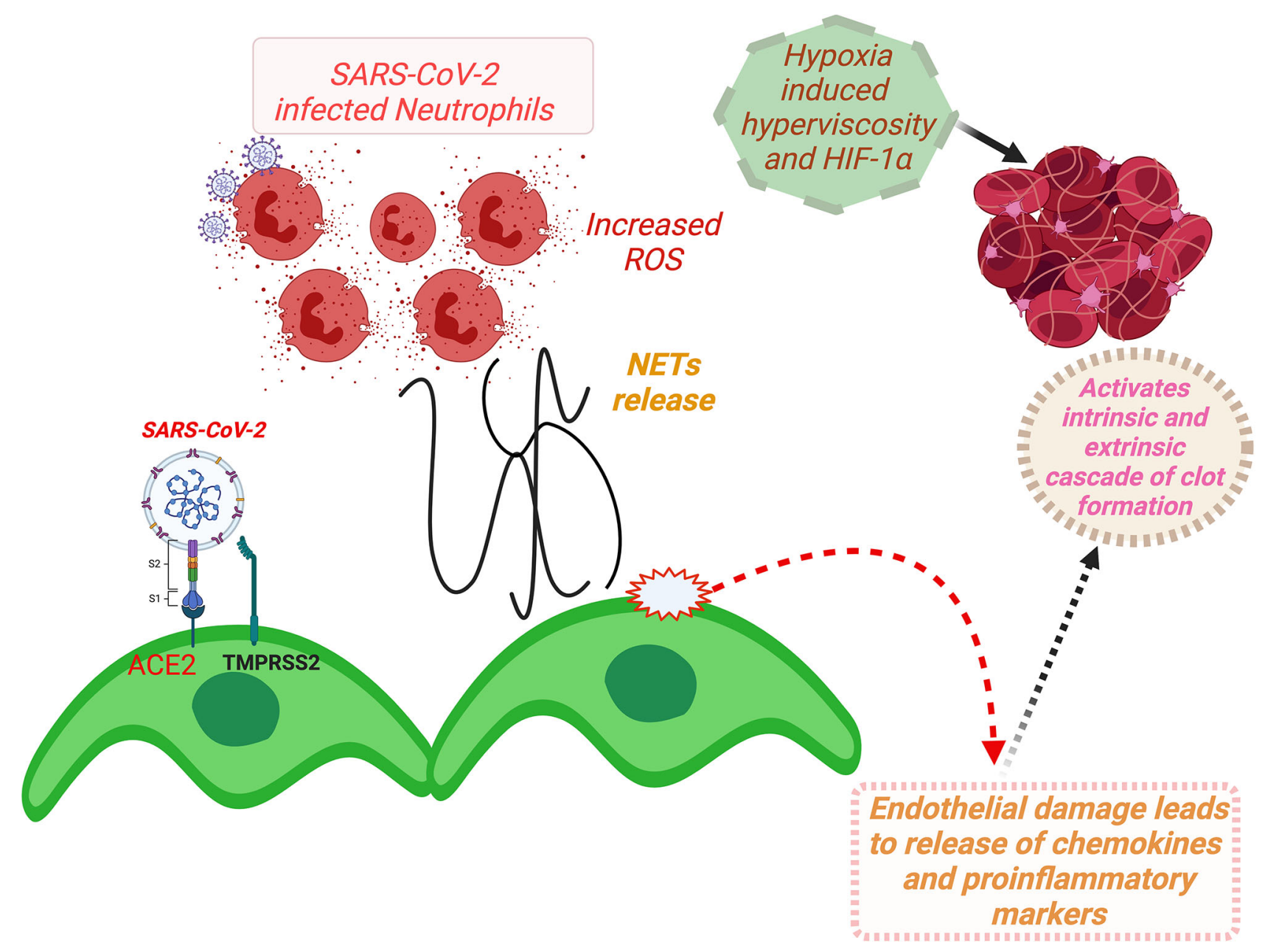

FIGURE 6 | A schema for ACE2-mediated dysfunction of vascular endothelium leading to thrombosis in COVID-19 patients. (Binding of SARS-CoV-2 to ACE2 receptor expressed at the vascular endothelial cell surface leads to internalization and replication of the virus inside the cell and consequently endothelial dysfunction that activates prothrombotic cascade. Additionally, SARS-CoV-2 binding induces downregulation of ACE2, resulting in imbalances of ACE/ACE2 ratio, and dysregulation of RAAS, favoring prothrombosis. Both of these stated mechanisms in consequence also induce activation and aggregation of the platelets, altogether culminating in intravascular thrombosis. Furthermore, NETs that cause increased concentrations of intracellular ROS in neutrophils inducing vascular endothelial dysfunction and activation of coagulation pathways. Furthermore, hypoxia-induced hyperviscosity and upregulation of the HIF-1 $\alpha$ signaling pathway can be contributing to the vascular thrombosis.) HIF-1 $\alpha$, hypoxia-inducible factor 1alpha; NETs, neutrophil extracellular traps; ROS, reactive oxygen species; ACE2, angiotensin-converting enzyme-2; TMPRSS2, transmembrane serine protease 2; COVID-19, coronavirus disease 2019; SARS-CoV-2, severe acute respiratory syndrome coronavirus 2; RAAS, renin-angiotensin-aldosterone system.

presents 4-6 weeks after SARS-CoV-2 infection as high fever and organ dysfunction, and patients show strongly elevated markers of inflammation. The pathogenesis of MIS-C is not yet clearly known. It has clinical features overlapping with Kawasaki disease suggestive of its being a vasculitis of an autoimmune etiology (120).

\section{Sex}

Significantly higher disease severity and mortality have been observed in men as compared to women (121). A breakdown of the current global sex-disaggregated data shows that for every 10 women, respectively, 10 men are infected, 12 men are hospitalized, 17 men are admitted to ICU, and 13 men are dead (https://globalhealth5050.org, dated 08/10/2021) (121).
The causal basis of why men are affected more in COVID-19 is yet not well understood. Various reasons have been suggested for this [Reviewed in (122)]. Higher expressions of SARS-CoV-2 host cell entry factors, ACE2 and TMPRSS2, in reproductive organs of men (123-125) and androgenic regulation of TMPRSS2 (126) are suggested biological reasons for poor outcomes in men. In contrast, $\mathrm{X}$-linkage and the estrogen-mediated regulation of multiple immune response genes including IFN type 1 and viral sensor TLR-7 could be the salient reasons why outcomes are comparatively better in women $(127,128)$.

\section{Comorbidities}

Comorbidities have been the most significant host factors contributing to COVID-19 severity. The most frequent 
contributors to COVID-19 have been respectively cardiovascular diseases, diabetes, chronic respiratory disease, hypertension, and obesity [Reviewed in (129)].

Hypertension and obesity may independently predict patient outcomes in COVID-19 $(130,131)$, and preexisting diabetes may increase the risks of having severe/critical COVID-19 illness and in-hospital mortality by, approximately, 2-fold and 3-fold, respectively $(129,132)$. The reasons for increased vulnerability for COVID-19 in the presence of comorbidities are yet not much understood. Plausibly, the residual damage and dysregulation of the pulmonary physiology, and also of the other vital organs, in the comorbid patients add to the COVID-19-induced pathology (129). A SARS-CoV-2 host cell entry receptor ACE2-mediated dysregulation of RAAS can also be implicated in this (45).

Obesity sets a state of chronic systemic inflammation and also changes the phenotypes of immune cells from anti-inflammatory to pro-inflammatory (Th2 to Th1 CD4 T cells and M2 to M1 macrophages) and induces increased secretion of proinflammatory adipocytokines, such as leptin, and decreased secretion of anti-inflammatory adipokines such as adiponectin, favoring a severe inflammatory response against any new infection (133). Thus, obesity may aggravate the COVID-19 pathology by inducing an early overwhelming inflammatory response against the viral infection, such as cytokine storms (134).

Prominent glycemic changes including the new onset of diabetes and increased complications in some COVID-19 patients have been noted in recent studies $(72,135)$. Increased mortality linked with diabetic complications has been frequent in patients with COVID-19 (132). SARS-CoV-2 can invade insulinproducing pancreatic islet cells (35). In addition, ACE2 mediated downregulation of sodium-glucose co-transporter 1 (SGLT1) in intestinal epithelium prevents hyperglycemia in rat models of diabetes mellitus (13). SARS-CoV-2-mediated downregulation of ACE2 expression can eventuality lead to upregulation of SGLT1, thereby precipitating hyperglycemia (13). Apart from the intestine, SGLT1 is also expressed in other human tissues like the proximal tubule of the kidney, heart, and liver (proteinatlas.org/ENSG00000100170-SLC5A1/tissue). Thus, an ACE2-mediated invasion of pancreatic islet cells and/or dysregulation of SGLT1 in intestinal epithelium may be plausible mechanisms for the new onset of diabetes in COVID-19 patients.

\section{Genetic and Immunophenotypic Factors}

Polymorphic variants are known for key SARS-CoV-2 host cell entry receptor ACE2 and associated host proteases, such as TMPRSS2 $(136,137)$ and furin (138). Possibly, some of these polymorphic variants of SARS-CoV-2 receptors may be more common in people showing low or high vulnerability for getting infected, or severity of symptoms and mortality, with COVID19 (137).

Studies suggest that mutations in host viral sensors and immune genes may be a reason for increased vulnerability for developing severe COVID-19. A mutation of toll-like receptor-7 (TLR-7) - a viral sensor (including for the coronaviruses) on host cells-is found to be associated with severe COVID-19 (102). Another study has reported that at least $3.5 \%$ of patients with life-threatening COVID-19 pneumonia had known mutations for immune response genes, viz., interferon regulatory factor 7 (IRF7) and interferon (IFN)-alpha receptor 1 and 2 (IFNAR1 and 2), TLR3, TIR domain-containing adapter molecule 1 (TICAM1), TANK-binding kinase 1 (TBK1), and IFN regulatory factor 3 (IRF3) (139).

Two genomic regions have been found particularly associated with severe COVID-19: one region on chromosome 3 (locus 3 p31.21) containing six genes and another region on chromosome 9 (locus 9q34.2) representing ABO blood groups $(21,140)$. Interestingly, the genetic variants on chromosome 3 [45,859,651-45,909,024 (hg19)] have entered the human population by a gene flow from archaic non-Homo sapiens hominids-Neanderthals (141). The genome-wide associations at multiple chromosomal loci other than 3 and 9 also have been reported, such as on chr12q24.13 (rs10735079) in a gene cluster encoding antiviral restriction enzyme activators (OAS1, OAS2, OAS3), on chr19p13.2 (rs2109069) near the gene encoding tyrosine kinase 2 (TYK2), on chr19p13.3 (rs2109069) within the gene encoding dipeptidyl peptidase 9 (DPP9), and on chr21q22.1 (rs2236757) in the IFNAR2 gene (103, 140). In contrast, a recent study found that a 75-kb haplotype on chromosome $12(113,350,796$ to $113,425,679$ base pairs, rs1156361) associated with a $\sim 22 \%$ reduction in relative risk of developing severe COVID-19 (142). Individuals with human leukocyte antigen (HLA) variants, $B^{\star} 46: 01$ and $B^{\star} 15: 03$, respectively, were suggested to bear more and less the susceptibility to SARS-CoV-2 and severity of COVID-19 (143).

The role of epigenetic mechanisms in host immune response in COVID-19 has also been demonstrated by a recent in vitro study using genome-editing CRISPR (clustered regularly interspaced short palindromic repeats) screens in Vero-E6 cells. Authors identified epigenetic regulatory molecules High mobility group box 1 (HMGB1) and SWItch/Sucrose Non-Fermentable (SWI/SNF) chromatin remodeling complex-critical for $\mathrm{CoV}$ induced host cell death, including SARS-CoV-2 (144).

People with blood group $\mathrm{O}$ were found to have slightly lesser chances of getting COVID-19 as well as relative protection from developing severe symptoms and death in comparison to persons with blood groups A, B, and AB (145-147). Of note, a very recent case-control study involving a very large data of COVID-19 patients (more than 11,000 positive cases) neither found increased risks in persons with $\mathrm{A}, \mathrm{B}$, and $\mathrm{AB}$ blood groups nor any protection for $\mathrm{O}$ blood group for contracting infection, hospitalization, disease severity, and outcomes (148).

Autoimmunity has also been an issue in the pathogenesis of severe symptoms in COVID-19. A study observed that at least $10.2 \%$ of the patients who are aged 25-87 years had autoantibodies against IFN type I, of which 95 (94\%) were men. A further instance of generation of autoantibodies in COVID-19 patients has been noted against host cell phospholipids (149). The presence of prothrombotic antiphospholipid (aPL) antibodies in the serum of COVID-19 patients could also be a reason for enhanced thrombotic 
incidences in some patients $(150,151)$. In contrast, a study by Borghi et al. (152) found a low prevalence of aPL in COVID-19 patients and no association between thrombosis and aPL.

\section{Gut Microbiome}

The gut microbiome is said to have a significant role in disease severity and patient outcomes in COVID-19, as they build up the local mucosal immunity against viral invasions (153). Recent studies showed that patients with COVID-19 have a different microbiome compared with controls, enriched with the opportunistic pathogens, and depletion of the beneficial commensals showed a correlation with severity of the symptoms $(65,154)$. The studies have further indicated that the composition of the gut microbiome may influence SARS$\mathrm{CoV}$-2-induced production of inflammatory cytokines and consequently in the onset of a cytokine storm $(65,153,155)$.

\section{Cross Immunity and Protection From Severe Disease}

SARS-CoV-2-reactive T cells and antibodies were found present in many individuals without a previous exposure $(156,157)$, indicating that previous infections with other CoVs might have caused this. Respiratory infections in humans by CoVs, especially those causing common cold are common. Accumulating evidence suggests that existing exposures to common cold strains can be protective from developing severe symptoms, if infected with SARS-CoV-2 (158). Apart from CoVs, infections with other respiratory viruses, recent flu shots (influenza vaccines), and childhood vaccinations with live attenuated bacteria/viruses, such as Bacille Calmette-Guerin (BCG) and measles-mumps-rubella (MMR) may be partially protective (159-162). The exact biological mechanisms for the protection are not known; however, an epigenetic mechanism leading to the "trained immunity" of the myeloid cells from the previous exposures to the related pathogens may be a plausible reason for this, with the information available from the existing literature (163).

\section{POSSIBLE PATHOPHYSIOLOGY OF "LONG COVID"}

Persistence or recurrence of the clinical symptoms as "long COVID" has turned up as a significant health issue in the discharged patients of COVID-19 (17-19). In addition to the persistence or recurrence of certain clinical symptoms, a possible risk of infertility in men, chronic fatigue, and the new onset of diabetes in COVID-19 survivors have been reported (17, 19, 72, 164). Furthermore, the formation of autoantibodies in many COVID-19 patients has been observed, which indicates that the survivors may have an increased risk of autoimmune disorders $(149,165)$. Newly developed disabilities $(165,166)$, and a likely decrease in life expectancy as being indicated by recent studies $(167,168)$, are other key concerns in the survivors. Long-term health issues are also noted in infection with other BCoVs, such as SARS-CoV-1 and MERS-CoV (169); however, the reasons have not been well understood yet. At present, its pathophysiology is not clearly understood; however, various speculations are being presented based on the known facts of the virus-host interactions in COVID-19. In general, the chronic illness and subsequent scarring and dysfunction of the affected organs may be the reasons for the long-term health issues (167). Apart from that, the chronic infection with SARS-CoV-2 may induce epigenetic changes in vital organs, thus reprogramming its functions, as have been recently demonstrated in a murine model of COVID-19, which may set the platform for long-term health issues (38). Profound inhibition of cell growth in the virally infected cells across the organs may be another potent molecular mechanism leading to long-term health issues (37). The cell growth inhibition may particularly affect the tissues with a high mitotic rate like reproductive and endocrine organs, mucosal and vascular epithelium, and neurogenic brain regions; hence, health issues, including those related to learning and memory may particularly arise in the long-term in COVID-19 survivors.

\section{CHANGING FACE OF THE PANDEMIC: A SHIFT IN HOST-VIRUS INTERACTIONS WITH EMERGING SARS-COV-2 VARIANTS}

The vast spread of the first COVID-19 wave beyond geographical boundaries had supposedly created an immunological barrier in the infected population against the wild-type (WT) SARS-CoV-2 strain (nCoV-2019), hopefully limiting recurrent waves. In a paradox, the massive new COVID-19 waves driven by emerging SARS-CoV-2 variants have appeared in the years 2020-2021 across the globe (170-173). The emerging SARS-CoV-2 variants, which seem to have greater transmissibility and virulence and are capable of escape against natural and acquired (from vaccines and therapeutically used monoclonal antibodies) immunity against the WT strains (172-175) (Table 2), have doomed the hope of a sooner ending of the pandemic. Recent in situ and animal models and clinical studies have confirmed that the variants have a shorter incubation period, higher viral load, and prolonged viral shedding (176-181). The variants may cause greater damage in the infected host tissue; however, if there has been a change in the tissue type/organ-specific pathogenesis is currently least understood (172). WHO has identified four variants of concerns (VOCs) and four variants of interest (VOIs) globally (173). The SARS-CoV-2 variants are characterized by lineage-specific key mutations in the spike protein regions, which are said to contribute to increased transmissibility and/or virulence and immune escape to natural and vaccine-acquired antibodies $(3,172,176,177)$ (Figure 7). Many of the spike protein mutations are shared across the variants indicating their convergent evolution and selective advantage for the epidemiological fitness (2) (Figure 7). The lineage-specific mutations are also present in the non-spike regions of the variants (182); however, currently, there is little known about their epidemiological significance. 
TABLE 2 | Emerging severe acute respiratory syndrome coronavirus 2 (SARS-CoV-2) variants across the globe and their clinical-epidemiological characteristics.

\begin{tabular}{|c|c|c|c|c|c|c|c|c|c|c|}
\hline $\begin{array}{l}\text { WHO } \\
\text { label }\end{array}$ & Pangolineages & $\begin{array}{l}\text { Variant } \\
\text { status } \\
\text { (WHO/ } \\
\text { CDC) }\end{array}$ & $\begin{array}{l}\text { GISAID } \\
\text { clade }\end{array}$ & Nextstrainclade & $\begin{array}{l}\text { Key Spike mutations } \\
\text { (frequency }>75 \%)^{\star}\end{array}$ & $\begin{array}{l}\text { First } \\
\text { reported }\end{array}$ & $\begin{array}{c}\text { Date of } \\
\text { designation }\end{array}$ & Transmission* & Lethality* & Immunoescape ${ }^{\star}$ \\
\hline Alpha & B.1.1.7 & $\begin{array}{l}\text { Variant of } \\
\text { concern } \\
\text { (VOC)\# }\end{array}$ & GRY & 201 (V1) & $\begin{array}{l}\text { 69del, 70del, 144del, } \\
\text { E484K, S494P, N501Y, } \\
\text { A570D, D614G, P681H, } \\
\text { T716I, S982A, D1118H } \\
\text { K1191N }\end{array}$ & $\begin{array}{l}\text { United } \\
\text { Kingdom, } \\
\text { Sep-2020 }\end{array}$ & 18-Dec-2020 & $\begin{array}{l}\sim 50 \% \text { increased } \\
\text { transmission } \\
\text { compared to B.1 }\end{array}$ & $\begin{array}{l}\text { Potential increased severity } \\
\text { based on hospitalizations } \\
\text { and case fatality rates }\end{array}$ & $\begin{array}{l}\text { - No impact on susceptibility } \\
\text { to monoclonal antibody } \\
\text { treatments } \\
\text { - Minimal impact on } \\
\text { neutralization by convalescent } \\
\text { and post-vaccination sera }\end{array}$ \\
\hline Beta & $\begin{array}{l}\text { B.1.351 } \\
\text { B.1.351.2 } \\
\text { B.1.351.3 }\end{array}$ & VOC\# & $\begin{array}{l}\text { GH/ } \\
\text { 501Y.V2 }\end{array}$ & $20 \mathrm{H}$ (V2) & $\begin{array}{l}\text { 69del, 70del, 144del, } \\
\text { E484K, S494P, N501Y, } \\
\text { A570D, D614G, P681H, } \\
\text { T716I, S982A, D1118H } \\
\text { K1191N }\end{array}$ & $\begin{array}{l}\text { South } \\
\text { Africa, } \\
\text { May-2020 }\end{array}$ & 18-Dec-2020 & $\begin{array}{l}\sim 50 \% \text { increased } \\
\text { transmission }\end{array}$ & More lethal & $\begin{array}{l}\text { - Significant decrease in } \\
\text { susceptibility to the combination } \\
\text { of bamlanivimab and } \\
\text { etesevimab monoclonal } \\
\text { antibody treatment } \\
\text { - Reduced neutralization by } \\
\text { convalescent and post- } \\
\text { vaccination sera }\end{array}$ \\
\hline Gamma & $\begin{array}{l}\text { P.1 } \\
\text { P. } 1.1 \\
\text { P.1.2 } \\
\text { P.1.4 } \\
\text { P.1.6 } \\
\text { P. } 1.7\end{array}$ & VOC\# & $\begin{array}{l}\text { GR/ } \\
\text { 501Y.V3 }\end{array}$ & 20J (V3) & $\begin{array}{l}\text { L18F, T20N, P26S, } \\
\text { D138Y, R190S, K417T, } \\
\text { E484K, N501Y, D614G, } \\
\text { H655Y, T1027I }\end{array}$ & $\begin{array}{l}\text { Brazil, } \\
\text { Nov-2020 }\end{array}$ & 11-Jan-2021 & Not ascertained yet & More lethal & $\begin{array}{l}\text { - Significant decrease in } \\
\text { susceptibility to the combination } \\
\text { of bamlanivimab and } \\
\text { etesevimab monoclonal } \\
\text { antibody treatment } \\
\text { - Reduced neutralization by } \\
\text { convalescent and post- } \\
\text { vaccination sera }\end{array}$ \\
\hline Delta & $\begin{array}{l}\text { B.1.617.2 } \\
\text { AY.1 } \\
\text { AY.2 } \\
\text { AY.3 } \\
\text { AY.3.1 }\end{array}$ & VOC\# & $\begin{array}{l}\text { G/ } \\
478 K . V 1\end{array}$ & $21 \mathrm{~A}$ & $\begin{array}{l}\text { T19R, (G142D), 156del, } \\
\text { 157del, R158G, L452R, } \\
\text { T478K, D614G, P681R, } \\
\text { D950N }\end{array}$ & $\begin{array}{l}\text { India, } \\
\text { Oct-2020 }\end{array}$ & $\begin{array}{l}\text { VOI: 4-Apr- } \\
2021 \\
\text { VOC: } 11- \\
\text { May-2021 }\end{array}$ & $\begin{array}{l}\sim 50-60 \% \text { increased } \\
\text { transmission } \\
\text { compared to } \\
\text { B.1.1.7 }\end{array}$ & $\begin{array}{l}\text { Preliminary results suggest } \\
2.61 \text { times higher the risk of } \\
\text { hospitalization within } 14 \text { days } \\
\text { compared with the B.1.1.7. }\end{array}$ & $\begin{array}{l}\text { - Potential reduction in } \\
\text { neutralization by some } \\
\text { monoclonal antibody treatments } \\
\text { - Potential reduction in } \\
\text { neutralization by post- } \\
\text { vaccination sera }\end{array}$ \\
\hline Lambda & C.37 & $\begin{array}{l}\text { Variant of } \\
\text { interest } \\
\text { (VOI) \# }\end{array}$ & $\begin{array}{l}\text { GR/ } \\
452 Q . V 1\end{array}$ & $21 G$ & $\begin{array}{l}\text { D614G, L452Q, F490S, } \\
\text { T859N, T76I, G75V, } \\
\text { del247/253 }\end{array}$ & $\begin{array}{l}\text { Peru, Dec- } \\
2020\end{array}$ & 14-Jun-2021 & Not ascertained yet & Not ascertained yet & - Not ascertained yet \\
\hline Mu & $\begin{array}{l}\text { B.1.621, } \\
\text { B.1.621.1 }\end{array}$ & VOI\# & $\mathrm{GH}$ & $21 \mathrm{H}$ & $\begin{array}{l}\text { Spike: T95I, Y144S, } \\
\text { Y145N, R346K, E484K, } \\
\text { N501Y, D614G, P681H, } \\
\text { D950N }\end{array}$ & $\begin{array}{l}\text { Colombia, } \\
\text { Jan-2021 }\end{array}$ & -Sep-2021 & 31-Aug-2021 & Not ascertained yet & - Not ascertained yet \\
\hline Eta & B.1.525 & $\begin{array}{l}\text { Variant } \\
\text { Being } \\
\text { Monitored } \\
(\text { VOB })^{*}\end{array}$ & $\begin{array}{l}\text { G/ } \\
484 K . V 3\end{array}$ & $21 \mathrm{D}$ & $\begin{array}{l}\text { A67V, 69del, 70del, } \\
\text { 144del, E484K, D614G, } \\
\text { Q677H, F888L }\end{array}$ & $\begin{array}{l}\text { Multiple } \\
\text { countries, } \\
\text { Dec-2020 }\end{array}$ & 17-Mar-2021 & Not ascertained yet & Not ascertained yet & $\begin{array}{l}\text { - Potential reduction in } \\
\text { neutralization by some } \\
\text { monoclonal antibody treatments } \\
\text { - Potential reduction in } \\
\text { neutralization by convalescent } \\
\text { and post-vaccination sera }\end{array}$ \\
\hline lota & B.1.526 & $\begin{array}{l}\text { Variant } \\
\text { Being } \\
\text { Monitored } \\
\text { (VOB) }^{\star}\end{array}$ & $\begin{array}{l}\text { GH/ } \\
253 G . V 1\end{array}$ & $21 \mathrm{~F}$ & $\begin{array}{l}\text { L5F, T95I, D253G, S477N, } \\
\text { E484K, D614G, A701V }\end{array}$ & $\begin{array}{l}\text { United } \\
\text { States of } \\
\text { America, } \\
\text { Nov-2020 }\end{array}$ & 24-Mar-2021 & Not ascertained yet & Not ascertained yet & $\begin{array}{l}\text { - Reduced susceptibility to } \\
\text { the combination of } \\
\text { bamlanivimab and etesevimab } \\
\text { monoclonal antibody treatment. }\end{array}$ \\
\hline
\end{tabular}

,




\section{PLAUSIBLE MECHANISMS FOR ENHANCED TRANSMISSIBILITY/ VIRULENCE AND IMMUNE ESCAPE CAPABILITIES IN VARIANTS}

Increased transmissibility and/or virulence has been reported for nearly all of the VOCs and multiple VOIs (174) (Table 2). The spike protein regions bear the binding site for the host cell entry receptor and the natural and acquired host antibodies. Key mutations in the spike protein (Table 2), chiefly in the receptor-binding domain (RBD), are believed to induce conformational changes resulting in stronger binding to the key host cell entry receptor ACE2 $(2,3)$. Moreover, certain mutations have created newer contact sites or stronger electrostatic or newer hydrogen bonds between RBD and host ACE2 (2) [Reviewed in $(176,177)]$.

Interestingly, the mutations in the spike protein sequence of certain variants (B.1.1.7 and B.1.617 lineage) occurring at amino acid position $681(\mathrm{P}-\mathrm{H} / \mathrm{R})$, which falls in the FCS, improve proteolytic cleavage of the spike protein strengthening fusion of the viral membrane with the host cell membrane [Reviewed in (1)]. An improved viral-host cell fusion may supposedly result in larger syncytia formation (1). Syncytia formation, a fusion of the infected host cell with other cells, is believed to facilitate viral spread, thus imparting higher transmissibility to the variants (183-185). Notably, syncytia formation has been a distinctive characteristic of SARS-CoV-2 when compared to SARS-CoV-1 [Reviewed in (1)].

Other than increased transmissibility and virulence, recent studies have shown that most of the variants, primarily VOCs, have gained a certain level of resistance against the natural and acquired (from vaccines and therapeutically used monoclonal antibodies) immunity (174) (Table 2). Frequent repeated and vaccine breakthrough infections have been reported with the variants $(172,186,187)$. The exact mechanisms for the gain of immune escape capabilities in variants are currently not well understood. Although, based on the emerging literature, the most likely immune escape mechanisms are (i) inclusion or deletion of amino acid residue at immunogenic epitopes (for the natural and acquired antibodies) bringing conformational changes at the binding interface $(2-4,176,177)$; (ii) remodeling of the electrostatic surface potential at the antigen-antibody binding interface $(2-4,176,177)$; and (iii) gain of additional glycosylation sites, which shield the binding site for the neutralizing antibodies (188). Future studies are warranted that can unravel the mechanisms that the variants utilize for the immune escape.

\section{CONCLUDING REMARKS}

Extensive research has been performed globally, unraveling the various mechanisms involved in the pathogenesis and host immune responses for COVID-19. These studies have mainly targeted viral proteomics and genomics and host-dependent factors. Extensive experimental studies have been conducted involving both cell 

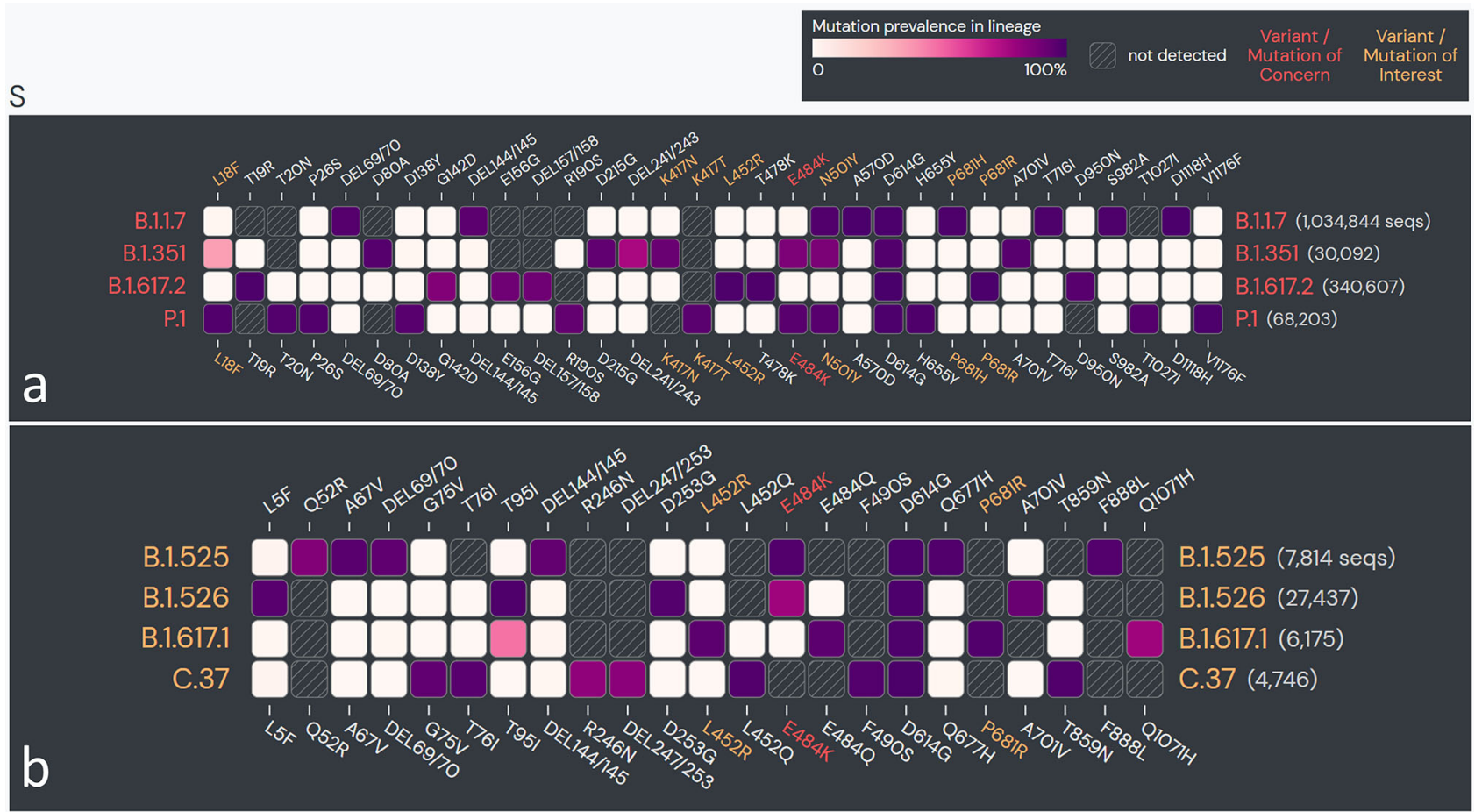

FIGURE 7 | The spike protein coding sequence mutations in emerging severe acute respiratory syndrome coronavirus 2 (SARS-CoV-2) variants globally. (A) Variants of concern (VOCs). (B) Variants of interest (VOIs). [Analysis included mutations with $>75 \%$ prevalence in at least one lineage currently recognized by World Health Organization (WHO) as variants of concern and variants of interest globally. Data source: www.outbreak.info, accessed on 28/08/2021].

culture-based and animal models of COVID-19. Furthermore, a human-specific adaptation of the viral-host interaction mechanisms has been derived from the laboratory data from the patients with COVID-19 and the experimental studies involving human tissue organoids. In light of the extensive findings achieved so far, we currently have a broad understanding of the virus-host interactions, tissue tropism and organ-specific pathogenesis, involvement of physiological systems, and the human immune response against the SARS-CoV-2 infection. The widespread expression of SARS-CoV-2 host cell entry factors across human tissue types, RAAS dysregulation, and a hyperactive innate immune response accompanied by delayed or suppressed adaptive immunity seem to be key factors behind systemic manifestations and poor clinical outcomes in the patients. The inclusion of FCS in the spike protein sequence may be a reason for the increased virulence of SARS-CoV-2. Additionally, dampening of the early IFN response and subsequent cytokine storm and suppressed/delayed adaptive immune response marked by intense lymphocytopenia and suboptimum synthesis of immunoglobulins are the prominent immunological features, which seem to drive the severity of the disease. The preexisting genetic factors may be the prime reason behind the increased vulnerability of certain individuals for contracting the infection and the severity of the disease; however, little is known on this issue yet. Gut microbiome may also have a significant role in disease outcomes as has been indicated from the emerging literature. Multiple knowledge gaps in aspects of the disease are remaining, which need to be addressed in future studies. Furthermore, the persistence or recurrence of the symptoms as "long COVID" is a very important health concern that needs to be intensively researched. Most importantly, the emerging SARS-CoV-2 variants driving recurrent COVID-19 waves, imparted by increased transmissibility/virulence and immune escape capabilities, requires further in-depth research to address its mechanism(s) precisely.

\section{AUTHOR CONTRIBUTIONS}

AK wrote the first draft. GK, SaK, CK, MK, PP, RN, VP, MF, PS, $\mathrm{KS}, \mathrm{KK}, \mathrm{SP}, \mathrm{HS}$, and SuK revised the draft. RN performed data analysis, and PP and RN prepared the figures. All authors contributed to the article and approved the submitted version.

\section{ACKNOWLEDGMENTS}

We acknowledge the help of the public databases, Human Protein Atlas (https://www.proteinatlas.org/) and Outbreak.info (https://outbreak.info/), for making available human transcriptomic and protein expression data and genomic sequences of SARS-CoV-2 variants, respectively, used in this article for generating figures. 


\section{REFERENCES}

1. Kumar A, Prasoon P, Kumari C, Pareek V, Faiq MA, Narayan RK, et al. SARS-CoV-2-Specific Virulence Factors in COVID-19. J Med Virol (2020) 93:1343-50. doi: 10.1002/jmv.26615

2. Gobeil SM-C, Janowska K, McDowell S, Mansouri K, Parks R, Stalls V, et al. Effect of Natural Mutations of SARS-CoV-2 on Spike Structure, Conformation, and Antigenicity. Science (80- ) (2021) 373(6555):eabi6226. doi: 10.1126/SCIENCE.ABI6226

3. Cai Y, Zhang J, Xiao T, Lavine CL, Rawson S, Peng H, et al. Structural Basis for Enhanced Infectivity and Immune Evasion of SARS-CoV-2 Variants. Science (80- ) (2021) 373:642-8. doi: 10.1126/SCIENCE.ABI9745

4. McCallum M, Bassi J, De Marco A, Chen A, Walls AC, Di Iulio J, et al. SARS-CoV-2 Immune Evasion by the B.1.427/B.1.429 Variant of Concern. Science (80- ) (2021) 373:648-54. doi: 10.1126/SCIENCE.ABI7994

5. Gupta A, Madhavan MV, Sehgal K, Nair N, Mahajan S, Sehrawat TS, et al. Extrapulmonary Manifestations of COVID-19. Nat Med (2020) 26:1017-32. doi: 10.1038/s41591-020-0968-3

6. Siordia JA. Epidemiology and Clinical Features of COVID-19: A Review of Current Literature. J Clin Virol (2020) 127:104357. doi: 10.1016/ j.jcv.2020.104357

7. Guan W, Ni Z, Hu Y, Liang W, Ou C, He J, et al. Clinical Characteristics of Coronavirus Disease 2019 in China. N Engl J Med (2020) 382:1708-20. doi: 10.1056/NEJMoa2002032

8. Mao L, Jin H, Wang M, Hu Y, Chen S, He Q, et al. Neurologic Manifestations of Hospitalized Patients With Coronavirus Disease 2019 in Wuhan, China. JAMA Neurol (2020) 77:683-90. doi: 10.1001/jamaneurol.2020.1127

9. Brown E, Gray R, Lo Monaco S, O’Donoghue B, Nelson B, Thompson A, et al. The Potential Impact of COVID-19 on Psychosis: A Rapid Review of Contemporary Epidemic and Pandemic Research. Schizophr Res (2020) 222:79-87. doi: 10.1016/j.schres.2020.05.005

10. Maharaj S, Bello Alvarez M, Mungul S, Hari K. Otologic Dysfunction in Patients With COVID-19: A Systematic Review. Laryngoscope Investig Otolaryngol (2020) 5:1192-6. doi: 10.1002/lio2.498

11. Wu P, Duan F, Luo C, Liu Q, Qu X, Liang L, et al. Characteristics of Ocular Findings of Patients With Coronavirus Disease 2019 (COVID-19) in Hubei Province, China. JAMA Ophthalmol (2020) 138:575-8. doi: 10.1001/ jamaophthalmol.2020.1291

12. Nishiga M, Wang DW, Han Y, Lewis DB, Wu JC. COVID-19 and Cardiovascular Disease: From Basic Mechanisms to Clinical Perspectives. Nat Rev Cardiol (2020) 17:543-58. doi: 10.1038/s41569-020-0413-9

13. Kumar A, Faiq MA, Pareek V, Raza K, Narayan RK, Prasoon P, et al. Relevance of SARS-CoV-2 Related Factors ACE2 and TMPRSS2 Expressions in Gastrointestinal Tissue With Pathogenesis of Digestive Symptoms, Diabetes-Associated Mortality, and Disease Recurrence in COVID-19 Patients. Med Hypotheses (2020) 144:110271. doi: 10.1016/j.mehy. 2020.110271

14. Gross O, Moerer O, Weber M, Huber TB, Scheithauer S. COVID-19-Associated Nephritis: Early Warning for Disease Severity and Complications? Lancet (2020) 395:e87-8. doi: 10.1016/S0140-6736(20)31041-2

15. Neri I, Guglielmo A, Virdi A, Gaspari V, Starace M, Piraccini BM. The Red Half-Moon Nail Sign: A Novel Manifestation of Coronavirus Infection. J Eur Acad Dermatol Venereol (2020) 34:e663-5. doi: 10.1111/jdv.16747

16. Marraha F, Al Faker I, Gallouj S. A Review of the Dermatological Manifestations of Coronavirus Disease 2019 (COVID-19). Dermatol Res Pract (2020) 127:104357. doi: 10.1155/2020/9360476

17. Sudre CH, Murray B, Varsavsky T, Graham MS, Penfold RS, Bowyer RC, et al. Attributes and Predictors of Long COVID. Nat Med (2021) 27:1-6. doi: 10.1038/s41591-021-01292-y

18. Mahase E. Covid-19: What do We Know About "Long Covid"? BMJ (2020) 370:m2815. doi: 10.1136/bmj.m2815

19. Tenforde MW, Kim SS, Lindsell CJ, Billig Rose E, Shapiro NI, Files DC, et al. Symptom Duration and Risk Factors for Delayed Return to Usual Health Among Outpatients With COVID-19 in a Multistate Health Care Systems Network - United States, March-June 2020. MMWR Morb Mortal Wkly Rep (2020) 69:993-8. doi: 10.15585/mmwr.mm6930e1

20. Kumar A, Prasoon P, Sekhawat PS, Pareek V, Faiq MA, Kumari C, et al. Pathogenesis Guided Therapeutic Management of COVID-19: An
Immunological Perspective. Int Rev Immunol (2020) 40:1-18. doi: $10.1080 / 08830185.2020 .1840566$

21. Thierry AR. Host/genetic Factors Associated With COVID-19 Call for Precision Medicine. Precis Clin Med (2020) 3:228-34. doi: 10.1093/ pcmedi/pbaa026

22. Zhang X, Tan Y, Ling Y, Lu G, Liu F, Yi Z, et al. Viral and Host Factors Related to the Clinical Outcome of COVID-19. Nature (2020) 583:1-7. doi: 10.1038/s41586-020-2355-0

23. Huang L, Yao Q, Gu X, Wang Q, Ren L, Wang Y, et al. 1-Year Outcomes in Hospital Survivors With COVID-19: A Longitudinal Cohort Study. Lancet (2021) 398:747-58. doi: 10.1016/S0140-6736(21)01755-4

24. Hoffmann M, Kleine-Weber H, Schroeder S, Krüger N, Herrler T, Erichsen S, et al. SARS-CoV-2 Cell Entry Depends on ACE2 and TMPRSS2 and Is Blocked by a Clinically Proven Protease Inhibitor. Cell (2020) 181:271-80.e8. doi: 10.1016/j.cell.2020.02.052

25. Coutard B, Valle C, de Lamballerie X, Canard B, Seidah NG, Decroly E. The Spike Glycoprotein of the New Coronavirus 2019-Ncov Contains a FurinLike Cleavage Site Absent in CoV of the Same Clade. Antiviral Res (2020) 176:104742. doi: 10.1016/j.antiviral.2020.104742

26. Braun E, Sauter D. Furin-Mediated Protein Processing in Infectious Diseases and Cancer. Clin Transl Immunol (2019) 8(8):e1073. doi: 10.1002/CTI2.1073

27. Xia S, Lan Q, Su S, Wang X, Xu W, Liu Z, et al. The Role of Furin Cleavage Site in SARS-CoV-2 Spike Protein-Mediated Membrane Fusion in the Presence or Absence of Trypsin. Signal Transduct Target Ther (2020) 5:13. doi: 10.1038/s41392-020-0184-0

28. Johnson BA, Xie X, Kalveram B, Lokugamage KG, Muruato A, Zou J, et al. Furin Cleavage Site Is Key to SARS-CoV-2 Pathogenesis. bioRxiv (2020) 2020.08.26.268854. doi: 10.1101/2020.08.26.268854

29. Cantuti-Castelvetri L, Ojha R, Pedro LD, Djannatian M, Franz J, Kuivanen S, et al. Neuropilin-1 Facilitates SARS-CoV-2 Cell Entry and Infectivity. Science (80- ) (2020) 370:eabd2985. doi: 10.1126/science.abd2985

30. Daly JL, Simonetti B, Klein K, Chen KE, Williamson MK, Antón-Plágaro C, et al. Neuropilin-1 is a Host Factor for SARS-CoV-2 Infection. Science (80- ) (2020) 370:861-5. doi: 10.1126/science.abd3072

31. Ziegler CGK, Allon SJ, Nyquist SK, Mbano IM, Miao VN, Tzouanas CN, et al. SARS-CoV-2 Receptor ACE2 Is an Interferon-Stimulated Gene in Human Airway Epithelial Cells and Is Detected in Specific Cell Subsets Across Tissues. Cell (2020) 181:1016-35.e19. doi: 10.1016/j.cell.2020.04.035

32. Sungnak W, Huang N, Bécavin C, Berg M, Queen R, Litvinukova M, et al. SARS-CoV-2 Entry Factors Are Highly Expressed in Nasal Epithelial Cells Together With Innate Immune Genes. Nat Med (2020) 26:1-7. doi: 10.1038/ s41591-020-0868-6

33. Muus C, Luecken MD, Eraslan G, Waghray A, Heimberg G, Sikkema L, et al. Integrated Analyses of Single-Cell Atlases Reveal Age, Gender, and Smoking Status Associations With Cell Type-Specific Expression of Mediators of SARSCoV-2 Viral Entry and Highlights Inflammatory Programs in Putative Target Cells. bioRxiv (2020) 2020.04.19.049254. doi: 10.1101/2020.04.19.049254

34. Deshmukh V, Motwani R, Kumar A, Kumari C, Raza K. Histopathological Observations in COVID-19: A Systematic Review. J Clin Pathol (2020) 74:18. doi: 10.1136/jclinpath-2020-206995

35. Yang L, Han Y, Nilsson-Payant BE, Gupta V, Wang P, Duan X, et al. A Human Pluripotent Stem Cell-Based Platform to Study SARS-CoV-2 Tropism and Model Virus Infection in Human Cells and Organoids. Cell Stem Cell (2020) 27:125-136.e7. doi: 10.1016/j.stem.2020.06.015

36. Bouhaddou M, Memon D, Swaney DL, Beltrao P, Krogan Correspondence NJ. The Global Phosphorylation Landscape of SARS-CoV-2 Infection. Cell (2020) 182:685-712. doi: 10.1016/j.cell.2020.06.034

37. Klann K, Bojkova D, Tascher G, Ciesek S, Münch C, Cinatl J. Growth Factor Receptor Signaling Inhibition Prevents SARS-CoV-2 Replication. Mol Cell (2020) 80:164-74. doi: 10.1016/j.molcel.2020.08.006

38. Li S, Ma F, Yokota T, Garcia G, Palermo A, Wang Y, et al. Metabolic Reprogramming and Epigenetic Changes of Vital Organs in SARS-CoV-2Induced Systemic Toxicity. JCI Insight (2021) 6:e145027. doi: 10.1172/ jci.insight. 145027

39. Thoms M, Buschauer R, Ameismeier M, Koepke L, Denk T, Hirschenberger $\mathrm{M}$, et al. Structural Basis for Translational Shutdown and Immune Evasion by the Nsp1 Protein of SARS-CoV-2. Science (2020) 369:1249-55. doi: $10.1126 /$ science.abc 8665 
40. Viswanathan T, Arya S, Chan S-H, Qi S, Dai N, Misra A, et al. Structural Basis of RNA Cap Modification by SARS-CoV-2. Nat Commun (2020) 11:3718. doi: 10.1038/s41467-020-17496-8

41. Anand P, Puranik A, Aravamudan M, Venkatakrishnan AJ, Soundararajan V. SARS-CoV-2 Strategically Mimics Proteolytic Activation of Human ENaC. Elife (2020) 9:e58603. doi: 10.7554/eLife.58603

42. Wynne BM, Zou L, Linck V, Hoover RS, Ma HP, Eaton DC. Regulation of Lung Epithelial Sodium Channels by Cytokines and Chemokines. Front Immunol (2017) 8:766. doi: 10.3389/fimmu.2017.00766

43. Mutchler SM, Kleyman TR. New Insights Regarding Epithelial Na+ Channel Regulation and Its Role in the Kidney, Immune System and Vasculature. Curr Opin Nephrol Hypertens (2019) 28:113-9. doi: 10.1097/MNH.0000000000000479

44. Chung MK, Karnik S, Saef J, Bergmann C, Barnard J, Lederman MM, et al. SARS-CoV-2 and ACE2: The Biology and Clinical Data Settling the ARB and ACEI Controversy. EBioMedicine (2020) 58:102907. doi: 10.1016/ j.ebiom.2020.102907

45. Kumar A, Narayan RK, Kumari C, Faiq MA, Kulandhasamy M, Kant K, et al. SARS-CoV-2 Cell Entry Receptor ACE2 Mediated Endothelial Dysfunction Leads to Vascular Thrombosis in COVID-19 Patients. Med Hypotheses (2020) 145:110320. doi: 10.1016/j.mehy.2020.110320

46. Mason RJ. Thoughts on the Alveolar Phase of COVID-19. Am J Physiol Cell Mol Physiol (2020) 319:L115-20. doi: 10.1152/ajplung.00126.2020

47. Ackermann M, Verleden SE, Kuehnel M, Haverich A, Welte T, Laenger F, et al. Pulmonary Vascular Endothelialitis, Thrombosis, and Angiogenesis in Covid-19. N Engl J Med (2020) 383:120-8. doi: 10.1056/nejmoa2015432

48. Sakamoto A, Kawakami R, Kawai K, Gianatti A, Pellegrini D, Kutys R, et al. ACE2 (Angiotensin-Converting Enzyme 2) and TMPRSS2 (Transmembrane Serine Protease 2) Expression and Localization of SARSCoV-2 Infection in the Human Heart. Arterioscler Thromb Vasc Biol (2020) 41:542-4. doi: 10.1161/ATVBAHA.120.315229

49. Babapoor-Farrokhran S, Gill D, Walker J, Rasekhi RT, Bozorgnia B, Amanullah A. Myocardial Injury and COVID-19: Possible Mechanisms. Life Sci (2020) 253:117723. doi: 10.1016/j.lfs.2020.117723

50. Lindner D, Fitzek A, Bräuninger H, Aleshcheva G, Edler C, Meissner K, et al. Association of Cardiac Infection With SARS-CoV-2 in Confirmed COVID-19 Autopsy Cases. JAMA Cardiol (2020) 5:1281-5. doi: 10.1001/jamacardio.2020.3551

51. South AM, Diz DI, Chappell MC. COVID-19, ACE2, and the Cardiovascular Consequences. Am J Physiol Heart Circ Physiol (2020) 318:H1084-90. doi: 10.1152/AJPHEART.00217.2020

52. Ingraham NE, Barakat AG, Reilkoff R, Bezdicek T, Schacker T, Chipman JG, et al. Understanding the Renin-Angiotensin-Aldosterone-SARS-CoV Axis: A Comprehensive Review. Eur Respir J (2020) 56:2000912. doi: 10.1183/ 13993003.00912-2020

53. Shaha KB, Manandhar DN, Cho JR, Adhikari A, K C MB. COVID-19 and the Heart: What We Have Learnt So Far. Postgrad Med J (2020) 97:655-66. doi: 10.1136/postgradmedj-2020-138284

54. Alfano G, Ferrari A, Fontana F, Perrone R, Mori G, Ascione E, et al. Hypokalemia in Patients With COVID-19. Clin Exp Nephrol (2021) 25:1-9. doi: 10.1007/s10157-020-01996-4

55. Chen Q-L, Li J-Q, Xiang Z-D, Lang Y, Guo G-J, Liu Z-H. Localization of Cell Receptor-Related Genes of SARS-CoV-2 in the Kidney Through Single-Cell Transcriptome Analysis. Kidney Dis (2020) 6:258-70. doi: 10.1159/000508162

56. Ronco C, Reis T. Kidney Involvement in COVID-19 and Rationale for Extracorporeal Therapies. Nat Rev Nephrol (2020) 16:308-10. doi: 10.1038/ s41581-020-0284-7

57. Ahmadian E, Hosseiniyan Khatibi SM, Razi Soofiyani S, Abediazar S, Shoja MM, Ardalan M, et al. Covid-19 and Kidney Injury: Pathophysiology and Molecular Mechanisms. Rev Med Virol (2020) 31:e2176. doi: 10.1002/rmv.2176

58. Bradley BT, Maioli H, Johnston R, Chaudhry I, Fink SL, Xu H, et al. Histopathology and Ultrastructural Findings of Fatal COVID-19 Infections in Washington State: A Case Series. Lancet (2020) 396:320-32. doi: 10.1016/ S0140-6736(20)31305-2

59. Zhou J, Li C, Liu X, Chiu MC, Zhao X, Wang D, et al. Infection of Bat and Human Intestinal Organoids by SARS-CoV-2. Nat Med (2020) 26:1-7. doi: 10.1038/s41591-020-0912-6

60. Lamers MM, Beumer J, van der Vaart J, Knoops K, Puschhof J, Breugem TI, et al. SARS-CoV-2 Productively Infects Human Gut Enterocytes. Science (80- ) (2020) 369:eabc1669. doi: 10.1126/science.abc1669
61. Jiao L, Li H, Xu J, Yang M, Ma C, Li J, et al. The Gastrointestinal Tract Is an Alternative Route for SARS-CoV-2 Infection in a Nonhuman Primate Model. Gastroenterology (2020) 160:1647-61. doi: 10.1053/j.gastro. 2020.12.001

62. Guo M, Tao W, Flavell RA, Zhu S. Potential Intestinal Infection and FaecalOral Transmission of SARS-CoV-2. Nat Rev Gastroenterol Hepatol (2021) 18:1-15. doi: 10.1038/s41575-021-00416-6

63. Hirose R, Nakaya T, Naito Y, Daidoji T, Watanabe Y, Yasuda H, et al. Mechanism of Human Influenza Virus RNA Persistence and Virion Survival in Feces: Mucus Protects Virions From Acid and Digestive Juices. J Infect Dis (2017) 216:105-9. doi: 10.1093/infdis/jix224

64. Sharma L, Riva A. Intestinal Barrier Function in Health and Disease-Any Role of Sars-Cov-2? Microorganisms (2020) 8:1-27. doi: 10.3390/ microorganisms 8111744

65. Gu S, Chen Y, Wu Z, Chen Y, Gao H, Lv L, et al. Alterations of the Gut Microbiota in Patients With Coronavirus Disease 2019 or H1N1 Influenza. Clin Infect Dis (2020) 71:2669-78. doi: 10.1093/cid/ciaa709

66. Azghandi M, Kerachian MA. Detection of Novel Coronavirus (SARS-CoV2) RNA in Peripheral Blood Specimens. J Transl Med (2020) 18:412. doi: 10.1186/s12967-020-02589-1

67. Buzhdygan TP, DeOre BJ, Baldwin-Leclair A, Bullock TA, McGary HM, Khan JA, et al. The SARS-CoV-2 Spike Protein Alters Barrier Function in 2D Static and 3D Microfluidic in-Vitro Models of the Human Blood-Brain Barrier. Neurobiol Dis (2020) 146:105131. doi: 10.1016/j.nbd.2020.105131

68. Patel KP, Patel PA, Vunnam RR, Hewlett AT, Jain R, Jing R, et al. Gastrointestinal, Hepatobiliary, and Pancreatic Manifestations of COVID19. J Clin Virol (2020) 128:104386. doi: 10.1016/j.jcv.2020.104386

69. Dong M, Zhang J, Ma X, Tan J, Chen L, Liu S, et al. ACE2, TMPRSS2 Distribution and Extrapulmonary Organ Injury in Patients With COVID19. BioMed Pharmacother (2020) 131:110678. doi: 10.1016/j.biopha. 2020.110678

70. Rubino F, Amiel SA, Zimmet P, Alberti G, Bornstein S, Eckel RH, et al. NewOnset Diabetes in Covid-19. N Engl J Med (2020) 383:789-90. doi: 10.1056/ nejmc 2018688

71. Gupta R, Hussain A, Misra A. Diabetes and COVID-19: Evidence, Current Status and Unanswered Research Questions. Eur J Clin Nutr (2020) 74:86470. doi: 10.1038/s41430-020-0652-1

72. Boddu SK, Aurangabadkar G, Kuchay MS. New Onset Diabetes, Type 1 Diabetes and COVID-19. Diabetes Metab Syndr Clin Res Rev (2020) 14 (6):2211-7. doi: 10.1016/J.DSX.2020.11.012

73. Gutiérrez-Ortiz C, Méndez A, Rodrigo-Rey S, San Pedro-Murillo E, Bermejo-Guerrero L, Gordo-Mañas R, et al. Miller Fisher Syndrome and Polyneuritis Cranialis in COVID-19. Neurology (2020) 95:e601-5. doi: 10.1212/wnl.0000000000009619

74. Moriguchi T, Harii N, Goto J, Harada D, Sugawara H, Takamino J, et al. A First Case of Meningitis/Encephalitis Associated With SARS-Coronavirus-2. Int J Infect Dis (2020) 94:55-8. doi: 10.1016/j.ijid.2020.03.062

75. Poyiadji N, Shahin G, Noujaim D, Stone M, Patel S, Griffith B. COVID-19Associated Acute Hemorrhagic Necrotizing Encephalopathy: CT and MRI Features. Radiology (2020) 201187:E119-20. doi: 10.1148/radiol.2020201187

76. Paterson RW, Brown RL, Benjamin L, Nortley R, Wiethoff S, Bharucha T, et al. The Emerging Spectrum of COVID-19 Neurology: Clinical, Radiological and Laboratory Findings. Brain (2020) 143:3104-20. doi: 10.1093/brain/awaa240

77. Varatharaj A, Thomas N, Ellul MA, Davies NWS, Pollak TA, Tenorio EL, et al. Neurological and Neuropsychiatric Complications of COVID-19 in 153 Patients: A UK-Wide Surveillance Study. Lancet Psychiatry (2020) 7:875-82. doi: 10.1016/s2215-0366(20)30287-x

78. Solomon IH, Normandin E, Bhattacharyya S, Mukerji SS, Keller K, Ali AS, et al. Neuropathological Features of Covid-19. N Engl J Med (2020) 383:98992. doi: 10.1056/nejmc2019373

79. Zhou L, Zhang M, Wang J, Gao J. Sars-Cov-2: Underestimated Damage to Nervous System. Travel Med Infect Dis (2020) 36:101642. doi: 10.1016/ j.tmaid.2020.101642

80. Kumar A, Pareek V, Prasoon P, Faiq MA, Kumar P, Kumari C, et al. Possible Routes of SARS-CoV-2 Invasion in Brain: In Context of Neurological Symptoms in COVID-19 Patients. J Neurosci Res (2020) 98:2376-83. doi: 10.1002/jnr.24717 
81. Bergmann CC, Lane TE, Stohlman SA. Coronavirus Infection of the Central Nervous System: Host-Virus Stand-Off. Nat Rev Microbiol (2006) 4:121-32. doi: $10.1038 / \mathrm{nrmicro} 1343$

82. Gu J, Korteweg C. Pathology and Pathogenesis of Severe Acute Respiratory Syndrome. Am J Pathol (2007) 170:1136-47. doi: 10.2353/ajpath.2007.061088

83. Beyrouti R, Adams ME, Benjamin L, Cohen H, Farmer SF, Goh YY, et al. Characteristics of Ischaemic Stroke Associated With COVID-19. J Neurol Neurosurg Psychiatry (2020) 91:889-91. doi: 10.1136/jnnp-2020-323586

84. Dorward DA, Russell CD, Um IH, Elshani M, Armstrong SD, Penrice-Randal $\mathrm{R}$, et al. Tissue-Specific Immunopathology in Fatal COVID-19. Am J Respir Crit Care Med (2021) 203:192-201. doi: 10.1164/rccm.202008-3265OC

85. Kumar A, Kumar S, Narayan RK, Kumari C, Pareek V, Prasoon P. Expression of SARS-CoV-2 Host Cell Entry Factors in Immune System Components of Healthy Individuals and Its Relevance for COVID-19 Immunopathology. Viral Immunol (2021) 34:352-3. doi: 10.1089/vim.2020.0277

86. Ryabkova VA, Churilov LP, Shoenfeld Y. Influenza Infection, SARS, MERS and COVID-19: Cytokine Storm - The Common Denominator and the Lessons to be Learned. Clin Immunol (2021) 223:108652. doi: 10.1016/j.clim.2020.108652

87. Olbei M, Hautefort I, Modos D, Treveil A, Poletti M, Gul L, et al. SARSCoV-2 Causes a Different Cytokine Response Compared to Other Cytokine Storm-Causing Respiratory Viruses in Severely Ill Patients. Front Immunol (2021) 12:629193. doi: 10.3389/fimmu.2021.629193

88. Channappanavar R, Fehr AR, Vijay R, Mack M, Zhao J, Meyerholz DK, et al. Dysregulated Type I Interferon and Inflammatory Monocyte-Macrophage Responses Cause Lethal Pneumonia in SARS-CoV-Infected Mice. Cell Host Microbe (2016) 19:181-93. doi: 10.1016/j.chom.2016.01.007

89. Blanco-Melo D, Nilsson-Payant BE, Liu WC, Uhl S, Hoagland D, Møller R, et al. Imbalanced Host Response to SARS-CoV-2 Drives Development of COVID-19. Cell (2020) 181:1036-1045.e9. doi: 10.1016/j.cell.2020.04.026

90. Konno Y, Kimura I, Uriu K, Fukushi M, Irie T, Koyanagi Y, et al. SARSCoV-2 ORF3b Is a Potent Interferon Antagonist Whose Activity Is Increased by a Naturally Occurring Elongation Variant. Cell Rep (2020) 32:108185. doi: 10.1016/j.celrep.2020.108185

91. Sun B, Feng Y, Mo X, Zheng P, Wang Q, Li P, et al. Kinetics of SARS-CoV-2 Specific IgM and IgG Responses in COVID-19 Patients. Emerg Microbes Infect (2020) 9:940-8. doi: 10.1080/22221751.2020.1762515

92. Sette A, Crotty S. Adaptive Immunity to SARS-CoV-2 and COVID-19. Cell (2021) 184:861. doi: 10.1016/j.cell.2021.01.007

93. Zhao Y, Kilian C, Turner J-E, Bosurgi L, Roedl K, Bartsch P, et al. Clonal Expansion and Activation of Tissue-Resident Memory-Like Th17 Cells Expressing GM-CSF in the Lungs of Severe COVID-19 Patients. Sci Immunol (2021) 6:eabf6692. doi: 10.1126/sciimmunol.abf6692

94. Thwaites RS, Sanchez Sevilla Uruchurtu A, Siggins MK, Liew F, Russell CD, Moore SC, et al. Inflammatory Profiles Across the Spectrum of Disease Reveal a Distinct Role for GM-CSF in Severe COVID-19. Sci Immunol (2021) 6:eabg9873. doi: 10.1126/sciimmunol.abg9873

95. Wagner J, DuPont A, Larson S, Cash B, Farooq A. Absolute Lymphocyte Count is a Prognostic Marker in Covid-19: A Retrospective Cohort Review. Int J Lab Hematol (2020) 42:761-5. doi: 10.1111/ijlh.13288

96. Chilimuri S, Sun H, Alemam A, Mantri N, Shehi E, Tejada J, et al. Predictors of Mortality in Adults Admitted With COVID-19: Retrospective Cohort Study From New York City. West J Emerg Med (2020) 21:779-84. doi: 10.5811/westjem.2020.6.47919

97. Tan L, Wang Q, Zhang D, Ding J, Huang Q, Tang YQ, et al. Lymphopenia Predicts Disease Severity of COVID-19: A Descriptive and Predictive Study. Signal Transduct Target Ther (2020) 5:1-3. doi: 10.1038/s41392-020-0148-4

98. Liu Q, Shi Y, Cai J, Duan Y, Wang R, Zhang H, et al. Pathological Changes in the Lungs and Lymphatic Organs of 12 COVID-19 Autopsy Cases. Natl Sci $\operatorname{Rev}(2020)$ 7:1868-78. doi: 10.1093/nsr/nwaa247

99. Elsoukkary SS, Mostyka M, Dillard A, Berman DR, Ma LX, Chadburn A, et al. Autopsy Findings in 32 Patients With COVID-19: A Single-Institution Experience. Pathobiology (2021) 88:56-68. doi: 10.1159/000511325

100. Diao B, Wang C, Tan Y, Chen X, Liu Y, Ning L, et al. Reduction and Functional Exhaustion of T Cells in Patients With Coronavirus Disease 2019 (COVID-19). Front Immunol (2020) 11:827. doi: 10.3389/fimmu.2020.00827

101. Channappanavar R, Perlman S. Pathogenic Human Coronavirus Infections: Causes and Consequences of Cytokine Storm and Immunopathology. Semin Immunopathol (2017) 39:529-39. doi: 10.1007/s00281-017-0629-x
102. van der Made CI, Simons A, Schuurs-Hoeijmakers J, van den Heuvel G, Mantere T, Kersten S, et al. Presence of Genetic Variants Among Young Men With Severe COVID-19. JAMA (2020) 324:663-73. doi: 10.1001/ jama.2020.13719

103. Pairo-Castineira E, Clohisey S, Klaric L, Bretherick AD, Rawlik K, Pasko D, et al. Genetic Mechanisms of Critical Illness in Covid-19. Nature (2020) 591:92-8. doi: 10.1038/s41586-020-03065-y

104. Bikdeli B, Madhavan MV, Jimenez D, Chuich T, Dreyfus I, Driggin E, et al. COVID-19 and Thrombotic or Thromboembolic Disease: Implications for Prevention, Antithrombotic Therapy, and Follow-Up. J Am Coll Cardiol (2020) 75:2950-73. doi: 10.1016/j.jacc.2020.04.031

105. McFadyen JD, Stevens H, Peter K. The Emerging Threat of (Micro) Thrombosis in COVID-19 and Its Therapeutic Implications. Circ Res (2020) 127:571-87. doi: 10.1161/circresaha.120.317447

106. Zhang S, Liu Y, Wang X, Yang L, Li H, Wang Y, et al. SARS-CoV-2 Binds Platelet ACE2 to Enhance Thrombosis in COVID-19. J Hematol Oncol (2020) 13:120. doi: 10.1186/s13045-020-00954-7

107. Lupi L, Adamo M, Inciardi RM, Metra M. ACE2 Down-Regulation may Contribute to the Increased Thrombotic Risk in COVID-19. Eur Heart $J$ (2020) 41:3200-0. doi: 10.1093/eurheartj/ehaa583

108. Verdecchia P, Cavallini C, Spanevello A, Angeli F. The Pivotal Link Between ACE2 Deficiency and SARS-CoV-2 Infection. Eur J Intern Med (2020) 76:14. doi: 10.1016/j.ejim.2020.04.037

109. Gao T, Hu M, Zhang X, Li H, Zhu L, Liu H, et al. Highly Pathogenic Coronavirus N Protein Aggravates Lung Injury by MASP-2-Mediated Complement Over-Activation. medRxiv (2020) 2020.03.29.20041962. doi: $10.1101 / 2020.03 .29 .20041962$

110. Zaim S, Chong JH, Sankaranarayanan V, Harky A. COVID-19 and Multiorgan Response. Curr Probl Cardiol (2020) 45:100618. doi: 10.1016/ j.cpcardiol.2020.100618

111. Connors JM, Levy JH. COVID-19 and Its Implications for Thrombosis and Anticoagulation. Blood (2020) 135:2033-40. doi: 10.1182/blood.2020006000

112. Sanyaolu A, Okorie C, Marinkovic A, Patidar R, Younis K, Desai P, et al. Comorbidity and Its Impact on Patients With COVID-19. SN Compr Clin Med (2020) 2:1069-76. doi: 10.1007/s42399-020-00363-4

113. Older Adults and COVID-19 | CDC. Available at: https://www.cdc.gov/ coronavirus/2019-ncov/need-extra-precautions/older-adults.html (Accessed December 4, 2020).

114. Coronavirus Age, Sex, Demographics (COVID-19) - Worldometer. Available at: https://www.worldometers.info/coronavirus/coronavirus-age-sexdemographics/ (Accessed November 24, 2020).

115. Crimmins EM. Age-Related Vulnerability to Coronavirus Disease 2019 (COVID-19): Biological, Contextual, and Policy-Related Factors. Public Policy Aging Rep (2020) 30:142-6. doi: 10.1093/ppar/praa023

116. Nikolich-Zugich J. The Twilight of Immunity: Emerging Concepts in Aging of the Immune System Review-Article. Nat Immunol (2018) 19:10-9. doi: 10.1038/s41590-017-0006-x

117. Darrigues J, van Meerwijk JPM, Romagnoli P. Age-Dependent Changes in Regulatory T Lymphocyte Development and Function: A Mini-Review. Gerontology (2018) 64:28-35. doi: 10.1159/000478044

118. Aviv A. Telomeres and COVID-19. FASEB J (2020) 34:7247-52. doi: 10.1096/fj.202001025

119. Ahmed M, Advani S, Moreira A, Zoretic S, Martinez J, Chorath K, et al. Multisystem Inflammatory Syndrome in Children: A Systematic Review. EClinicalMedicine (2020) 26:100527. doi: 10.1016/j.eclinm.2020.100527

120. Rowley AH, Shulman ST, Arditi M. Immune Pathogenesis of COVID-19Related Multisystem Inflammatory Syndrome in Children. J Clin Invest (2020) 130:5619-21. doi: 10.1172/JCI143840

121. Dataset | Global Health 50/50. Available at: https://globalhealth5050.org/thesex-gender-and-covid-19-project/dataset/ (Accessed October 13, 2020).

122. Kumar A, Narayan RK, Kulandhasamy M, Prasoon P, Kumari C, Kumar S, et al. COVID-19 Pandemic: Insights Into Molecular Mechanisms Leading to Sex-Based Differences in Patient Outcomes. Expert Rev Mol Med (2021) 23: e7. doi: 10.1017/ERM.2021.9

123. Shen $\mathrm{Q}$, Xiao X, Aierken $\mathrm{A}$, Yue $\mathrm{W}, \mathrm{Wu} \mathrm{X}$, Liao $\mathrm{M}$, et al. The ACE2 Expression in Sertoli Cells and Germ Cells may Cause Male Reproductive Disorder After SARS-CoV-2 Infection. J Cell Mol Med (2020) 24:9472-7. doi: $10.1111 /$ jcmm.15541 
124. Wang Z, Xu X. scRNA-Seq Profiling of Human Testes Reveals the Presence of the ACE2 Receptor, A Target for SARS-CoV-2 Infection in Spermatogonia, Leydig and Sertoli Cells. Cells (2020) 9:920. doi: 10.3390/ cells 9040920

125. Tissue Expression of TMPRSS2 - Summary - The Human Protein Atlas. Available at: https://www.proteinatlas.org/ENSG00000184012-TMPRSS2/ tissue (Accessed May 14, 2020).

126. Montopoli M, Zumerle S, Vettor R, Rugge M, Zorzi M, Catapano CV, et al. Androgen-Deprivation Therapies for Prostate Cancer and Risk of Infection by SARS-CoV-2: A Population-Based Study (N\&nbsp;= 4532). Ann Oncol (2020) 31:1040-5. doi: 10.1016/j.annonc.2020.04.479

127. Bunders MJ, Altfeld M. Implications of Sex Differences in Immunity for SARS-CoV-2 Pathogenesis and Design of Therapeutic Interventions. Immunity (2020) 53:487-95. doi: 10.1016/j.immuni.2020.08.003

128. Klein SL, Flanagan KL. Sex Differences in Immune Responses. Nat Rev Immunol (2016) 16:626-38. doi: 10.1038/nri.2016.90

129. Ejaz H, Alsrhani A, Zafar A, Javed H, Junaid K, Abdalla AE, et al. COVID-19 and Comorbidities: Deleterious Impact on Infected Patients. J Infect Public Health (2020) 13:1833-9. doi: 10.1016/j.jiph.2020.07.014

130. Pan W, Zhang J, Wang M, Ye J, Xu Y, Shen B, et al. Clinical Features of COVID-19 in Patients With Essential Hypertension and the Impacts of Renin-Angiotensin-Aldosterone System Inhibitors on the Prognosis of COVID-19 Patients. Hypertension (2020) 76:732-41. doi: 10.1161/ HYPERTENSIONAHA.120.15289

131. Klang E, Kassim G, Soffer S, Freeman R, Levin MA, Reich DL. Severe Obesity as an Independent Risk Factor for COVID-19 Mortality in Hospitalized Patients Younger Than 50. Obesity (2020) 28:1595-9. doi: 10.1002/oby.22913

132. Mantovani A, Byrne CD, Zheng MH, Targher G. Diabetes as a Risk Factor for Greater COVID-19 Severity and in-Hospital Death: A Meta-Analysis of Observational Studies. Nutr Metab Cardiovasc Dis (2020) 30:1236-48. doi: 10.1016/j.numecd.2020.05.014

133. Ignacio RMC, Kim C-S, Kim S-K. Immunological Profiling of Obesity. J Lifestyle Med (2014) 4:1-7. doi: 10.15280/jlm.2014.4.1.1

134. Lui B, Samuels JD, White RS. Potential Pathophysiology of COVID-19 in Patients With Obesity. Br J Anaesth (2020) 125:e283-4. doi: 10.1016/j.bja.2020.05.055

135. Li J, Wang X, Chen J, Zuo X, Zhang H, Deng A. COVID-19 Infection may Cause Ketosis and Ketoacidosis. Diabetes Obes Metab (2020) 22:1935-41. doi: $10.1111 /$ dom. 14057

136. Hou Y, Zhao J, Martin W, Kallianpur A, Chung MK, Jehi L, et al. New Insights Into Genetic Susceptibility of COVID-19: An ACE2 and TMPRSS2 Polymorphism Analysis. BMC Med (2020) 18:216. doi: 10.1186/s12916-020-01673-z

137. Singh H, Choudhari R, Nema V, Khan AA. ACE2 and TMPRSS2 Polymorphisms in Various Diseases With Special Reference to Its Impact on COVID-19 Disease. Microb Pathog (2020) 150:104621. doi: 10.1016/ j.micpath.2020.104621

138. Luostari K, Hartikainen JM, Tengström M, Palvimo JJ, Kataja V, Mannermaa A, et al. Type II Transmembrane Serine Protease Gene Variants Associate With Breast Cancer. PloS One (2014) 9:e102519. doi: 10.1371/journal.pone.0102519

139. Zhang Q, Bastard P, Liu Z, Le Pen J, Moncada-Velez M, Chen J, et al. Inborn Errors of Type I IFN Immunity in Patients With Life-Threatening COVID19. Science (2020) 370:eabd4570. doi: 10.1126/science.abd4570

140. COVID-19 Host Genetics Initiative. Mapping the Human Genetic Architecture of COVID-19. Nature (2021) 2021:1-8. doi: 10.1038/s41586021-03767-x

141. Zeberg H, Pääbo S. The Major Genetic Risk Factor for Severe COVID-19 is Inherited From Neanderthals. Nature (2020) 587:610-2. doi: 10.1038/ s41586-020-2818-3

142. Zeberg H, Pääbo S. A Genomic Region Associated With Protection Against Severe COVID-19 is Inherited From Neandertals. Proc Natl Acad Sci (2021) 118:e2026309118. doi: 10.1073/pnas.2026309118

143. Godri Pollitt KJ, Peccia J, Ko AI, Kaminski N, Dela Cruz CS, Nebert DW, et al. COVID-19 Vulnerability: The Potential Impact of Genetic Susceptibility and Airborne Transmission. Hum Genomics (2020) 14:17. doi: 10.1186/s40246-020-00267-3

144. Wei J, Alfajaro MM, DeWeirdt PC, Hanna RE, Lu-Culligan WJ, Cai WL, et al. Genome-Wide CRISPR Screens Reveal Host Factors Critical for SARSCoV-2 Infection. Cell (2020) 184:1-16. doi: 10.1016/j.cell.2020.10.028
145. Barnkob MB, Pottegård A, Støvring H, Haunstrup TM, Homburg K, Larsen $\mathrm{R}$, et al. Reduced Prevalence of SARS-CoV-2 Infection in ABO Blood Group O. Blood Adv (2020) 4:4990-3. doi: 10.1182/bloodadvances.2020002657

146. Hoiland RL, Fergusson NA, Mitra AR, Griesdale DEG, Devine DV, Stukas S, et al. The Association of ABO Blood Group With Indices of Disease Severity and Multiorgan Dysfunction in COVID-19. Blood Adv (2020) 4:4981-9. doi: 10.1182/bloodadvances.2020002623

147. Latz CA, DeCarlo C, Boitano L, Png CYM, Patell R, Conrad MF, et al. Blood Type and Outcomes in Patients With COVID-19. Ann Hematol (2020) 99:2113-8. doi: 10.1007/s00277-020-04169-1

148. Anderson JL, May HT, Knight S, Bair TL, Muhlestein JB, Knowlton KU, et al. Association of Sociodemographic Factors and Blood Group Type With Risk of COVID-19 in a US Population. JAMA Netw Open (2021) 4:e217429. doi: 10.1001/jamanetworkopen.2021.7429

149. Zuo Y, Estes SK, Ali RA, Gandhi AA, Yalavarthi S, Shi H, et al. Prothrombotic Autoantibodies in Serum From Patients Hospitalized With COVID-19. Sci Transl Med (2020) 12:eabd3876. doi: 10.1126/ scitranslmed.abd 3876

150. Devreese KMJ, Linskens EA, Benoit D, Peperstraete H. Antiphospholipid Antibodies in Patients With COVID-19: A Relevant Observation? J Thromb Haemost (2020) 18:2191-201. doi: 10.1111/jth.14994

151. Zhang Y, Xiao M, Zhang S, Xia P, Cao W, Jiang W, et al. Coagulopathy and Antiphospholipid Antibodies in Patients With Covid-19. N Engl J Med (2020) 382:e38. doi: 10.1056/nejmc2007575

152. Borghi MO, Beltagy A, Garrafa E, Curreli D, Cecchini G, Bodio C, et al. AntiPhospholipid Antibodies in COVID-19 Are Different From Those Detectable in the Anti-Phospholipid Syndrome. Front Immunol (2020) 11:584241. doi: 10.3389/fimmu.2020.584241

153. Dhar D, Mohanty A. Gut Microbiota and Covid-19- Possible Link and Implications. Virus Res (2020) 285:198018. doi: 10.1016/j.virusres. 2020.198018

154. Zuo T, Zhang F, Lui GCY, Yeoh YK, Li AYL, Zhan H, et al. Alterations in Gut Microbiota of Patients With COVID-19 During Time of Hospitalization. Gastroenterology (2020) 159:944-55.e8. doi: 10.1053/ j.gastro.2020.05.048

155. Tao W, Zhang G, Wang X, Guo M, Zeng W, Xu Z, et al. Analysis of the Intestinal Microbiota in COVID-19 Patients and Its Correlation With the Inflammatory Factor IL-18. Med Microecol (2020) 5:100023. doi: 10.1016/ j.medmic.2020.100023

156. Ng KW, Faulkner N, Cornish GH, Rosa A, Harvey R, Hussain S, et al. Preexisting and De Novo Humoral Immunity to SARS-CoV-2 in Humans. Science (80- ) (2020) eabe1107:1339-43. doi: 10.1126/science.abe1107

157. Mateus J, Grifoni A, Tarke A, Sidney J, Ramirez SI, Dan JM, et al. Selective and Cross-Reactive SARS-CoV-2 T Cell Epitopes in Unexposed Humans. Science (80- ) (2020) 370:89-94. doi: 10.1126/science.abd3871

158. Sagar M, Reifler K, Rossi M, Miller NS, Sinha P, White L, et al. Recent Endemic Coronavirus Infection Is Associated With Less Severe COVID-19. J Clin Invest (2020) 131:e143380. doi: 10.1172/jci143380

159. Fidel PL, Noverr MC. Could an Unrelated Live Attenuated Vaccine Serve as a Preventive Measure to Dampen Septic Inflammation Associated With Covid-19 Infection? MBio (2020) 11:1-4. doi: 10.1128/mBio.00907-20

160. Fink G, Orlova-Fink N, Schindler T, Grisi S, Ferrer APS, Daubenberger C, et al. Inactivated Trivalent Influenza Vaccination is Associated With Lower Mortality Among Patients With COVID-19 in Brazil. BMJ Evid Based Med (2020) bmjebm-2020-111549. doi: 10.1136/bmjebm-2020-111549

161. Gold JE, Baumgartl WH, Okyay RA, Licht WE, Fidel PL, Noverr MC, et al. Analysis of Measles-Mumps-Rubella (MMR) Titers of Recovered COVID-19 Patients. MBio (2020) 11:e02628-20. doi: 10.1128/mBio.02628-20

162. Beric-Stojsic B, Kalabalik-Hoganson J, Rizzolo D, Roy S. Childhood Immunization and COVID-19: An Early Narrative Review. Front Public Health (2020) 8:587007. doi: 10.3389/fpubh.2020.587007

163. de Laval B, Maurizio J, Kandalla PK, Brisou G, Simonnet L, Huber C, et al. C/ Ebp $\beta$-Dependent Epigenetic Memory Induces Trained Immunity in Hematopoietic Stem Cells. Cell Stem Cell (2020) 26:657-74.e8. doi: $10.1016 /$ j.stem.2020.01.017

164. Li H, Xiao X, Zhang J, Zafar MI, Wu C, Long Y, et al. Impaired Spermatogenesis in COVID-19 Patients. EClinicalMedicine (2020) 28:100604. doi: 10.1016/j.eclinm.2020.100604 
165. Bastard P, Rosen LB, Zhang Q, Michailidis E, Hoffmann HH, Zhang Y, et al. Autoantibodies Against Type I IFNs in Patients With Life-Threatening COVID-19. Science (2020) 370:eabd4585. doi: 10.1126/science.abd4585

166. De Lorenzo R, Conte C, Lanzani C, Benedetti F, Roveri L, Mazza MG, et al. Residual Clinical Damage After COVID-19: A Retrospective and Prospective Observational Cohort Study. PloS One (2020) 15:e0239570. doi: 10.1371/ journal.pone. 0239570

167. Pifarré i Arolas H, Acosta E, López-Casasnovas G, Lo A, Nicodemo C, Riffe T, et al. Years of Life Lost to COVID-19 in 81 Countries. Sci Rep (2021) 11:3504. doi: 10.1038/s41598-021-83040-3

168. Aburto JM, Schöley J, Kashnitsky I, Zhang L, Rahal C, Missov TI, et al. Quantifying Impacts of the COVID-19 Pandemic Through Life-Expectancy Losses: A Population-Level Study of 29 Countries. Int J Epidemiol (2021) dyab207. doi: 10.1093/IJE/DYAB207

169. O'Sullivan O. Long-Term Sequelae Following Previous Coronavirus Epidemics. Clin Med (2021) 21:e68-70. doi: 10.7861/clinmed.2020-0204

170. Faria NR, Mellan TA, Whittaker C, Claro IM, Candido D da S, Mishra S, et al. Genomics and Epidemiology of the P.1 SARS-CoV-2 Lineage in Manaus, Brazil. Science (80-) (2021) 372:815-21. doi: 10.1126/science.abh2644

171. Kumar A, Dwivedi P, Kumar G, Narayan RK, Jha RK, Parashar R, et al. Second Wave of COVID-19 in India Could be Predicted With Genomic Surveillance of SARS-CoV-2 Variants Coupled With Epidemiological Data: A Tool for Future. medRxiv (2021) 2021.06.09.21258612. doi: 10.1101/ 2021.06.09.21258612

172. Kumar A, Parashar R, Faiq MA, Kumar S, Kumari C, Kulandhasamy M, et al. Emerging SARS-CoV-2 Variants Can Potentially Break Set Epidemiological Barriers in COVID-19. SSRN Electron J (2021). doi: 10.2139/SSRN.3888058

173. Tracking SARS-CoV-2 Variants. Available at: https://www.who.int/en/ activities/tracking-SARS-CoV-2-variants/ (Accessed June 17, 2021).

174. SARS-CoV-2 Variant Classifications and Definitions. Available at: https:// www.cdc.gov/coronavirus/2019-ncov/variants/variant-info.html (Accessed June 25, 2021).

175. Twohig KA, Nyberg T, Zaidi A, Thelwall S, Sinnathamby MA, Aliabadi S, et al. Hospital Admission and Emergency Care Attendance Risk for SARSCoV-2 Delta (B.1.617.2) Compared With Alpha (B.1.1.7) Variants of Concern: A Cohort Study. Lancet Infect Dis (2021) S1473-3099(21)004758. doi: 10.1016/S1473-3099(21)00475-8

176. Luan B, Huynh T. Insights Into SARS-CoV-2's Mutations for Evading Human Antibodies: Sacrifice and Survival. J Med Chem (2021) 10.1021/ acs.jmedchem.1c00311. doi: 10.1021/acs.jmedchem.1c00311

177. Harvey WT, Carabelli AM, Jackson B, Gupta RK, Thomson EC, Harrison EM, et al. SARS-CoV-2 Variants, Spike Mutations and Immune Escape. Nat Rev Microbiol (2021) 19:409-24. doi: 10.1038/s41579-021-00573-0

178. Horspool AM, Ye C, Wong TY, Russ BP, Lee KS, Winters MT, et al. SARSCoV-2 B.1.1.7 and B.1.351 Variants of Concern Induce Lethal Disease in K18-Hace2 Transgenic Mice Despite Convalescent Plasma Therapy. bioRxiv Prepr Serv Biol (2021). doi: 10.1101/2021.05.05.442784

179. Yadav PD, Mohandas S, Shete AM, Nyayanit DA, Gupta N, Patil DY, et al. SARS CoV-2 Variant B.1.617.1 is Highly Pathogenic in Hamsters Than B.1 Variant. bioRxiv (2021) 2021.05.05.442760. doi: 10.1101/2021.05.05.442760
180. Li B, Deng A, Li K, Hu Y, Li Z, Xiong Q, et al. Viral Infection and Transmission in a Large, Well-Traced Outbreak Caused by the SARSCoV-2 Delta Variant. medRxiv (2021) 2021.07.07.21260122. doi: 10.1101/ 2021.07.07.21260122

181. Montagutelli X, Prot M, Levillayer L, Salazar EB, Jouvion G, Conquet L, et al. The B1.351 and P.1 Variants Extend SARS-CoV-2 Host Range to Mice. bioRxiv (2021) 2021.03.18.436013. doi: 10.1101/2021.03.18.436013

182. SARS-CoV-2 (hCoV-19) Mutation Reports. Outbreak.Info. Available at: https://outbreak.info/situation-reports?pango=AY.1\&loc=IND\&loc= GBR\&loc=USA (Accessed August 28, 2021).

183. Hoffmann M, Kleine-Weber H, Pöhlmann S. A Multibasic Cleavage Site in the Spike Protein of SARS-CoV-2 Is Essential for Infection of Human Lung Cells. Mol Cell (2020) 78:779-784.e5. doi: 10.1016/j.molcel.2020.04.022

184. Tang T, Bidon M, Jaimes JA, Whittaker GR, Daniel S. Coronavirus Membrane Fusion Mechanism Offers a Potential Target for Antiviral Development. Antiviral Res (2020) 178:104792. doi: 10.1016/ j.antiviral.2020.104792

185. Planas D, Veyer D, Baidaliuk A, Staropoli I, Guivel-Benhassine F, Rajah MM, et al. Reduced Sensitivity of SARS-CoV-2 Variant Delta to Antibody Neutralization. Nature (2021) 2021:1-7. doi: 10.1038/s41586-021-03777-9

186. Hacisuleyman E, Hale C, Saito Y, Blachere NE, Bergh M, Conlon EG, et al. Vaccine Breakthrough Infections With SARS-CoV-2 Variants. N Engl J Med (2021) 384:2212-8. doi: 10.1056/nejmoa2105000

187. Kustin T, Harel N, Finkel U, Perchik S, Harari S, Tahor M, et al. Evidence for Increased Breakthrough Rates of SARS-CoV-2 Variants of Concern in BNT162b2-mRNA-Vaccinated Individuals. Nat Med (2021) 27:1-6. doi: 10.1038/s41591-021-01413-7

188. Ge A, Rioux M, Kelvin AA, Ca AK, Kelvin A. Computational Assessment of the Spike Protein Antigenicity Reveals Diversity in B Cell Epitopes But Stability in T Cell Epitopes Across SARS-CoV-2 Variants. bioRxiv (2021) 2021.03.25.437035. doi: 10.1101/2021.03.25.437035

Conflict of Interest: The authors declare that the research was conducted in the absence of any commercial or financial relationships that could be construed as a potential conflict of interest.

Publisher's Note: All claims expressed in this article are solely those of the authors and do not necessarily represent those of their affiliated organizations, or those of the publisher, the editors and the reviewers. Any product that may be evaluated in this article, or claim that may be made by its manufacturer, is not guaranteed or endorsed by the publisher.

Copyright (c) 2021 Kumar, Narayan, Prasoon, Kumari, Kaur, Kumar, Kulandhasamy, Sesham, Pareek, Faiq, Pandey, Singh, Kant, Shekhawat, Raza and Kumar. This is an open-access article distributed under the terms of the Creative Commons Attribution License (CC BY). The use, distribution or reproduction in other forums is permitted, provided the original author(s) and the copyright owner(s) are credited and that the original publication in this journal is cited, in accordance with accepted academic practice. No use, distribution or reproduction is permitted which does not comply with these terms. 